DOI: $10.6060 / \mathrm{mhc} 170512 \mathrm{a}$

\title{
Thiacalix[4]arene's Lower Rim Derivatives: Synthesis and Supramolecular Properties
}

\author{
Svetlana E. Solovieva, ${ }^{\mathrm{a}, \mathrm{b}}$ Vladimir A. Burilov, ${ }^{\mathrm{a}}$ and Igor S. Antipina ${ }^{\mathrm{a}, \mathrm{b}}$ \\ ${ }^{a}$ Kazan Federal University, 420008 Kazan, Russian Federation \\ ${ }^{\mathrm{b}}$ A.E. Arbuzov Institute of Organic and Physical Chemistry of Kazan Scientific Centre of Russian Academy of Sciences, \\ 420088 Kazan, Russian Federation \\ @Corresponding authorE-mail: iantipin54@yandex.ru
}

\begin{abstract}
A consolidated review on the synthesis of lower rim tetrasubstituted thiacalixarenes and their self-assembly on the soft surfaces contributed from our group is presented. The approaches for the synthesis of different types of tetra-Osubstituted thiacalixarenes from the last 10 years are discussed. In addition, amphiphilic macrocycles in 1,3-alternate conformation form monolayers at the interface and are effectively embedded into the vesicles. Decorated by thiacalixarenes nanolayers and vesicles demonstrate a high selectivity towards specific analytes.
\end{abstract}

Keywords: Thiacalix[4]arene, synthetic methods, amphiphile, molecular recognition.

\section{Производные тиакаликс[4]арена по нижнему ободу: синтез и супрамолекулярные свойства}

\author{
С. Е. Соловьева, ${ }_{1}^{\text {a,b }}$ B. А. Бурилов, ${ }^{a}$ И. С. Антипин ${ }^{\mathrm{a}, \mathrm{@}}$ \\ ${ }^{\mathrm{a}}$ Казанский федеральный университет, 420008 Казань, Российская Федерация \\ ${ }^{\mathrm{b}}$ Институт органической и физической химии Казанского научного иентра РАН, 420088 Казань, Российская \\ Федераичя \\ @E-mail: iantipin54@yandex.ru
}

\begin{abstract}
Представлен сводный обзор работ, выполненных в нашей научной группе, по синтезу замещуенных по нижнему ободу тиакаликсаренов и их самосборке на мягких поверхностях. Обсуждаются подходы к синтезу различных типов тетра-О-замещенных тиакаликсаренов, полученных в последние 10 лет. Показано, что амфифильные макрочикль в стереоизмерной форме 1,3-альтернат образуют монослои на поверхностях и эффективно встраиваются в везикульл. Нанослои и везикуль,, декорированные производныли тиакаликсарена, проявляют высокую селективность по отношению к ряду аналитов.
\end{abstract}

Ключевые слова: Тиакаликс[4]арены, синтетические методы, амфифилы, молекулярное распознавание.

\section{Introduction}

The synthesis of the novel host molecules is a challenging topic in the field of supramolecular chemistry because of these compounds play principal role in the design of advanced functional materials and devices such as highly sensitive and selective sensors, photo-switchable luminescent and magnetic materials, high-performance catalysts etc. For a molecular receptor to be an effective host, its basic molecular scaffold should be easily synthesized and modified to enhance molecular recognition ability toward relevant guest molecules. Last three decades great attention has been drawn to the calix[n]arenes as molecular scaffold for the host molecules design. ${ }^{[1-6]}$ Later thiacalix[4]arene, firstly described by Miyano, ${ }^{[7]}$ became a very attractive class of calixarene family that can be tuned to serve as efficient host for different guests either by modulating their conformation or by modifying the nature and number of ligating 


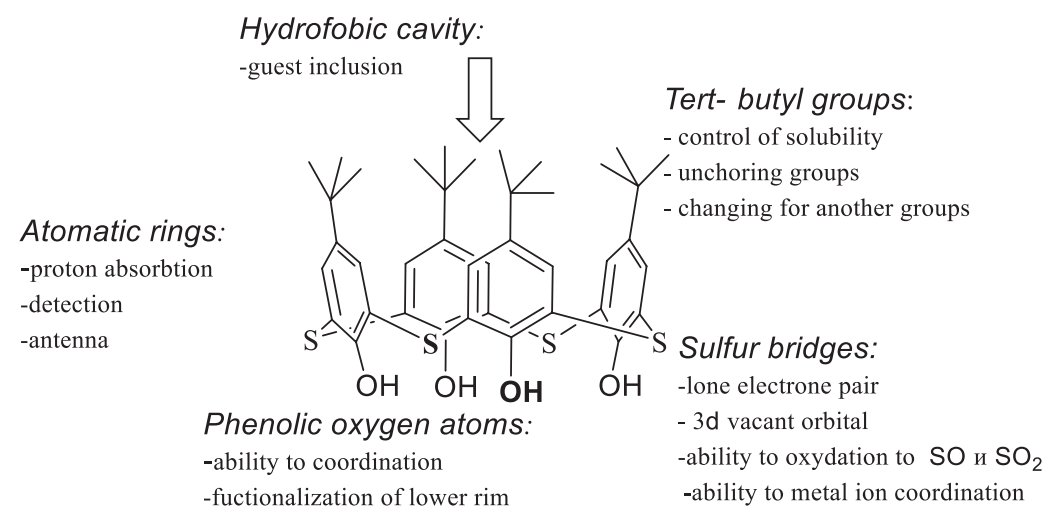

Figure 1. Structural features of the calixarene platform to tune molecular recognition properties.

sites ${ }^{[8-14]}$ Attractive features of thiacalix[4] arene scaffold for the design of the host molecules are presented in Figure 1.

Thiacalix[4]arenes like conventional calix[4]arenes are capable of adopting the four principal conformations depending on the orientation of the phenolic units with respect to each other: cone, partial cone, 1,2- and 1,3 alternates as shown in Figure 2.

Parent thiacalix[4]arenes 1, 2 always exists in the cone conformation in solution and solid phase due to the favorable intramolecular circular hydrogen bonds formed between adjacent phenolic groups. But they are significantly weaker than in case of conventional calix[4]arene $\left(26-28 \mathrm{kcal} \cdot \mathrm{mol}^{-1}\right.$ for the classic calixarenes and $20-21 \mathrm{kcal} \cdot \mathrm{mol}^{-1}$ for the thiacalixarenes) ${ }^{[15-17]}$ because of the ring size of thiacalix[4]arene is $15 \%$ larger than that of calix[4] arene due to the longer bond length of $\mathrm{C}-\mathrm{S}$ as compared to $\mathrm{C}-\mathrm{C}$. For this reason thiacalix[4] arene scaffold is more flexible and easily undergoes conformational changes during the complexation or derivatization. Due to high molecular structure flexibility and a metal-binding ability (the presence of sulfur bridges) thiacalixarenes are superior to conventional calixarenes for the design of supramolecular architectures. Moreover, a chemical modification of thiacalix[4]arene on the upper or lower rims with suitable ligating sites can enhance many times its ability to the intermolecular interactions with different guest molecules. In this context, the greatest interest is lower rim tetrasubstituted derivatives as tetradentant ligands possessing high efficiency and selectivity to form host-guest complexes and to bind both organic molecules and metal ions.
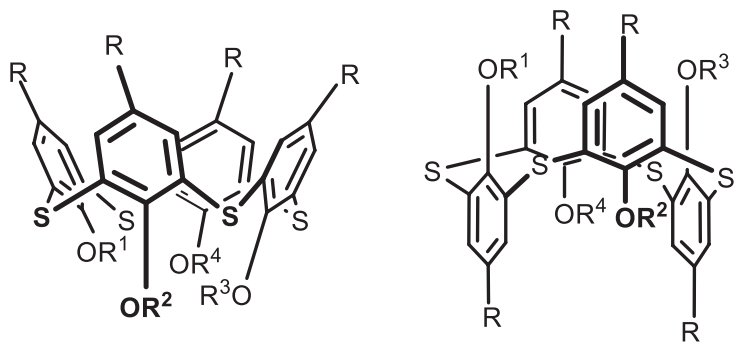

To date, a series of reviews on various aspects of chemistry thiacalixarene was published. ${ }^{[8-14]}$ In this review, we have focused and highlighted our recent findings of (i) synthesis of lower rim tetrasubstituted derivatives of thiacalixarene, and (ii) design of thiacalixarene-based amphiphilic receptor molecules and their application for the sensing technique.

\section{Results and Discussion}

\section{Synthesis of Tetrasubstituted Thiacalix[4]arene Derivatives}

Chemical modification of the lower rim of thiacalix[4]arenes is similar to that of calix[4]arenes, although the bridging sulfide groups significantly modify the reactivity pattern of thiacalix[4]arenes as compared to calix[4]arenes. Different functional groups can be introduced on the thiacalix[4]arene lower rim by simple base-catalyzed etherification (Williamson synthesis). A general method for the functionalization of all phenolic groups is the interaction of macrocycle with the excess of halogen derivatives in dipolar aprotic solvents (mainly, in acetone or acetonitrile) in the presence of alkali metal carbonates $\mathrm{M}_{2} \mathrm{CO}_{3}$ as a base. Reaction of $\mathbf{1}$ and $\mathbf{2}$ with simple alkyl halides (RI or $\mathrm{RBr}, \mathrm{R}>\mathrm{C}_{3} \mathrm{H}_{7}$ ) in the presence of base generally gives the tetraalkylated products in 1,3-alternate conformation. ${ }^{[9,10,13]}$ In the case of electrophilic reagents containing $n$-donor

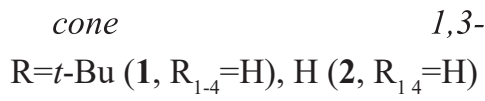

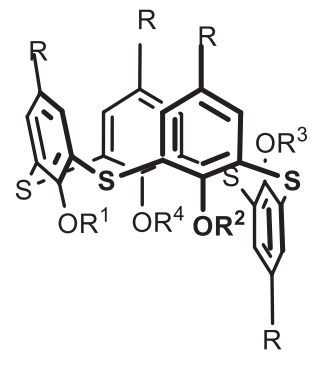

partial cone

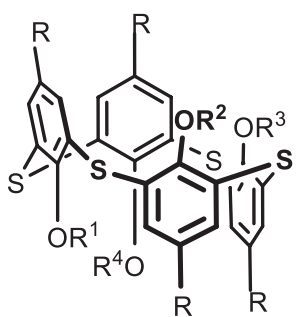

1,2-alternate

Figure 2. Principal thiacalix[4]arene conformations. 
groups, ${ }^{[9,10,13,18-20]}$ the reaction occurs stereospecifically and is governed by the metal template effects of $\mathrm{M}_{2} \mathrm{CO}_{3}\left(\mathrm{M}=\mathrm{Na}^{+}\right.$, $\mathrm{K}^{+}, \mathrm{Cs}^{+}$). So, three conformational isomers of tetrasubstituted products out of the possible four, i.e. cone, partial cone, and 1,3-alternate can be selectively obtained. Tetrasubstituted derivatives 3-18 obtained by base-catalyzed etherification of macrocycles $\mathbf{1}$ and $\mathbf{2}$ are shown on Scheme 1.

These derivatives are conformationally rigid (except the compounds 12,13) and cannot change their steroisomeric form during further modification. So, they are useful precursors to synthesize wide series of amines, amides, hydrazides and other functional derivatives (compounds 2366) (Schemes 1, 2).
Easily available by the Newman-Kwart rearrangement tetramercaptothiacalix[4]arene $\mathbf{6 7}^{[57]}$ adopting 1,3-alternate conformation $^{[58]}$ undergoes easily base-catalyzed etherification with the formation of carboxyl, pyrazolyl, ${ }^{[31]}$ cyanopropoxy, ${ }^{[59]}$ cyanobenzyloxy ${ }^{[59]}$ and $\alpha, \beta, \gamma$ pyridylmethoxy ${ }^{[60]}$ derivatives 68-71 (Scheme 3).

\section{Synthesis of Bifunctional Tetrasubstituted Thiacalix[4] arene Derivatives in the 1,3-Alternate Conformation}

Bifunctional tetrasubstituted thiacalix[4]arene derivatives in the 1,3-alternate stereoisomeric form (Figure 3)

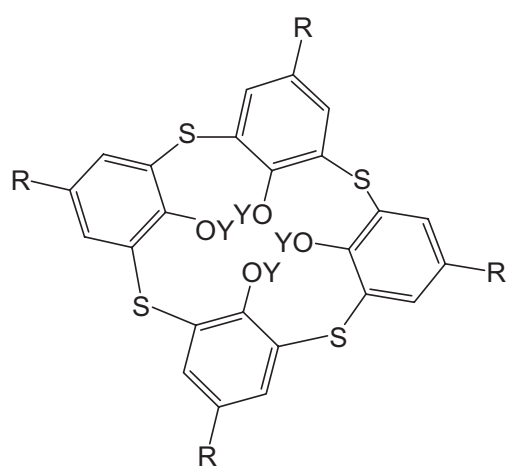

Scheme 1 .
3: $\mathrm{R}=t-\mathrm{Bu} ; \mathrm{Y}=\left(\mathrm{CH}_{2}\right)_{\mathrm{n}} \mathrm{Br}, \mathrm{n}=2-5 ;{ }^{[21]}$

4: $\mathrm{R}=t-\mathrm{Bu} ; \mathrm{Y}=\mathrm{CH}_{2} \mathrm{C}(\mathrm{O}) \mathrm{N}(\mathrm{Et}) ;{ }^{[19]}$

5: $\mathrm{R}=\mathrm{H} ; \mathrm{Y}=\mathrm{CH}_{2} \mathrm{C}(\mathrm{O}) \mathrm{N}(\mathrm{Et}){ }_{2} ;[20]$

6: $\mathrm{R}=t-\mathrm{Bu} ; \mathrm{Y}={ }^{2} \mathrm{H}_{2} \mathrm{C}(\mathrm{S}) \mathrm{N}(\mathrm{Et}){ }^{;}{ }^{[22]}$

7: $\mathrm{R}=t-\mathrm{Bu} ; \mathrm{Y}=\mathrm{CH}_{2} \mathrm{C}(\mathrm{O}) \mathrm{Ph} ;{ }^{[18]}$

8: $\mathrm{R}=\mathrm{H} ; \mathrm{Y}=\mathrm{CH}_{2} \mathrm{C}(\mathrm{O}) \mathrm{Ph} ;{ }^{[20]}$

9: $\mathrm{R}=t-\mathrm{Bu} ; \mathrm{Y}=\mathrm{N}-$ propoxyphtalimide; ${ }^{[23,24]}$

10: $\mathrm{R}=t-\mathrm{Bu} ; \mathrm{Y}=\left(\mathrm{CH}_{2}\right)_{3} \mathrm{CN} ;{ }^{[25]}$

11: $\mathrm{R}=\mathrm{H} ; \mathrm{Y}=\left(\mathrm{CH}_{2}\right)_{3} \mathrm{CN} ;{ }^{[26]}$

12: $\mathrm{R}=t$-Bu; $\mathrm{Y}=\mathrm{CH}_{2} \mathrm{C} \equiv \mathrm{CH} ;{ }^{[27]}$

13: $\mathrm{R}=\mathrm{H} ; \mathrm{Y}=\mathrm{CH}_{2} \mathrm{C} \equiv \mathrm{CH} ;{ }^{[27]}$

14: $\mathrm{R}=t-\mathrm{Bu} ; \mathrm{Y}=\left(\mathrm{CH}_{2}\right)_{\mathrm{n}} \mathrm{C} \equiv \mathrm{CH}, \mathrm{n}=3-6 ;{ }^{[28]}$

15: $\mathrm{R}=t-\mathrm{Bu} ; \mathrm{Y}=\left(\mathrm{CH}_{2} \mathrm{Py}(\alpha, \beta, \gamma){ }^{[29]}\right.$
16: $\mathrm{R}=\mathrm{H} ; \mathrm{Y}=\left(\mathrm{CH}_{2} \mathrm{Py}(\alpha, \beta, \gamma) ;{ }^{[30]}\right.$

17: $\mathrm{R}=t-\mathrm{Bu} ; \mathrm{Y}=\left(\mathrm{CH}_{2}\right)_{\mathrm{n}}$-pyrazolyl, $\mathrm{n}=2-4 ; ;^{[31]}$

18: $\mathrm{R}=t-\mathrm{Bu} ; \mathrm{Y}=\mathrm{CH}_{2} \mathrm{C}_{6} \mathrm{H}_{4} \mathrm{CN} ;$;32]

19: $\mathrm{R}=t-\mathrm{Bu}, \mathrm{Y}=\mathrm{CH}_{2} \mathrm{COOEt} ;{ }^{[33,34]}$

20: $\mathrm{R}=\mathrm{H}, \mathrm{Y}=\mathrm{CH}_{2} \mathrm{COOEt}$; $[35]$

21: $\mathrm{R}=t-\mathrm{Bu}, \mathrm{Y}=\mathrm{CH}_{2} \mathrm{COOH} ;{ }^{[36]}$

22: $\mathrm{R}=t-\mathrm{Bu}, \mathrm{Y}=\mathrm{CH}_{2} \mathrm{COCl}^{\left[{ }^{[37]}\right.}$

23: $\mathrm{R}=t-\mathrm{Bu} ; \mathrm{Y}=\left(\mathrm{CH}_{2}\right)_{\mathrm{n}} \mathrm{SH}, \mathrm{n}=2-5 ;{ }^{[21]}$

24: $\mathrm{R}=t-\mathrm{Bu} ; \mathrm{Y}=\left(\mathrm{CH}_{2}\right)_{\mathrm{n}} \mathrm{S}-$ terPy, $\mathrm{n}=2-5 ;{ }^{[38]}$

25: $\mathrm{R}=t$-Bu; $\mathrm{Y}=\left(\mathrm{CH}_{2}\right)_{3} \mathrm{NH}_{2},{ }^{[39]}$

26: $\mathrm{NHC}(\mathrm{O}) \mathrm{NHPh} ;{ }^{[39]}$

27: $\mathrm{R}=t-\mathrm{Bu} ; \mathrm{Y}=\left(\mathrm{CH}_{2}\right)_{3} \mathrm{NH}\left(\mathrm{NH}_{2}\right)_{2}{ }^{+} \mathrm{Cl}-;[40]$

28: $\mathrm{R}=t$-Bu; $\mathrm{Y}=\left(\mathrm{CH}_{2}\right)_{3} \mathrm{NHP}(\mathrm{O}) \mathrm{OEt}_{2} \cdot{ }^{[41]}$

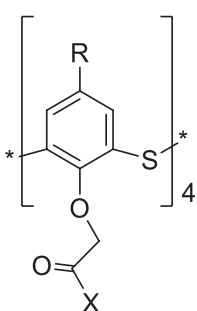

29: $\mathrm{R}=t-\mathrm{Bu}, \mathrm{X}=-\stackrel{\mathrm{N}}{\text {;[42] }}$

30: $\mathrm{R}=t-\mathrm{Bu}, \mathrm{X}=\stackrel{-\mathrm{N}}{\mathrm{O}_{;[43]}}$

31: $\mathrm{R}=t$-Bu, $\mathrm{X}=\stackrel{\mathrm{H}}{-\mathrm{N}} ;$;43]

32: $\mathrm{R}=t-\mathrm{Bu}, \mathrm{X}=\mathrm{NHCH}_{2} \mathrm{C}_{6} \mathrm{H}_{5} ;{ }^{[43]}$

33: $\mathrm{R}=t-\mathrm{Bu}, \mathrm{X}=\mathrm{NH}\left(\mathrm{CH}_{2}\right)_{7} \mathrm{CH}_{3} ;{ }^{[43]}$

34: $\mathrm{R}=t-\mathrm{Bu}, \mathrm{X}=\mathrm{NHCH}_{2} \mathrm{C}_{6} \mathrm{H}_{4} \mathrm{CH}_{3}{ }^{[43]}$

35: $\mathrm{R}=t$-Bu, $\mathrm{X}=\mathrm{NH}\left(\mathrm{CH}_{2}\right)_{11} \mathrm{CH}_{3}{ }^{[44]}$

36: $\mathrm{R}=t-\mathrm{Bu}, \mathrm{X}=\mathrm{NH}\left(\mathrm{CH}_{2}\right)_{17} \mathrm{CH}_{3} ;{ }^{[44]}$

37: $\mathrm{R}=t-\mathrm{Bu}, \mathrm{X}=\mathrm{NHC}_{6} \mathrm{H}_{4} \mathrm{~N}=\mathrm{N}-\mathrm{C}_{6} \mathrm{H}_{5} ;{ }^{[45]}$

38: $\mathrm{R}=t-\mathrm{Bu}, \mathrm{X}=\mathrm{NH}$

39: $\mathrm{R}=t$-Bu, $\mathrm{X}=\mathrm{N}\left(\mathrm{CH}_{2}\right)_{2} \mathrm{OCOMe} ;{ }^{[46]}$

40: $\mathrm{R}=t-\mathrm{Bu}, \mathrm{X}=\mathrm{N}\left(\mathrm{CH}_{2}\right)_{2} \mathrm{OH} ;{ }^{[46]}$
41: $\mathrm{R}=\mathrm{t}-\mathrm{Bu}, \mathrm{X}=\stackrel{\mathrm{N}}{\mathbb{N}}{ }_{;[4]}^{\mathrm{N}}$

42: $\mathrm{R}=t-\mathrm{Bu}, \mathrm{X}=\stackrel{\mathrm{N}}{\mathrm{N}}$; $[47]$

43: $\mathrm{R}=t-\mathrm{Bu}, \mathrm{X}={ }_{\mathrm{N}} ;{ }^{[47]}$

$\mathrm{HN} \longrightarrow \mathrm{N}$

44: $\mathrm{R}=t-\mathrm{Bu}, \mathrm{X}=\mathrm{V}_{;}[47]$ $\mathrm{HN}$

45: $\mathrm{R}=t-\mathrm{Bu}, \mathrm{X}=$<smiles>[3H]NCc1c[nH+][c-](C)c1</smiles>

46: $\mathrm{R}=t-\mathrm{Bu}, \mathrm{X}=\mathrm{N}$
47: $\mathrm{R}=t-\mathrm{Bu}, \mathrm{X}=\mathrm{NH}\left(\mathrm{CH}_{2}\right)_{3} \mathrm{~N}^{+}\left(\mathrm{CH}_{3}\right)_{3} ;{ }^{; 48]}$

48: $\mathrm{R}=t-\mathrm{Bu}$,

$\mathrm{X}=\mathrm{NH}\left(\mathrm{CH}_{2}\right)_{3} \mathrm{~N}^{+}\left(\mathrm{CH}_{3}\right)_{2} \mathrm{C}_{2} \mathrm{H}_{5} ;{ }^{[48]}$

49: $\mathrm{R}=t$-Bu,

$\mathrm{X}=\mathrm{NH}\left(\mathrm{CH}_{2}\right)_{3} \mathrm{~N}^{+}\left(\mathrm{CH}_{3}\right)_{2} \mathrm{CH}_{2} \mathrm{C}_{6} \mathrm{H}_{5} ;$; ${ }^{[48]}$

50: $\mathrm{R}=t-\mathrm{Bu}$,

$\mathrm{X}=\mathrm{NH}\left(\mathrm{CH}_{2}\right)_{3} \mathrm{~N}^{+}\left(\mathrm{CH}_{3}\right)_{2} \mathrm{CH}_{2} \mathrm{COOEt} ;{ }^{[48]}$

51: $\mathrm{R}=t-\mathrm{Bu}, \mathrm{X}=$

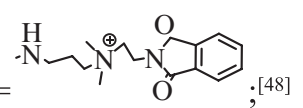

52: $\mathrm{R}=t-\mathrm{Bu}, \mathrm{X}=\mathrm{N}\left(\mathrm{CH}_{2} \mathrm{CH}_{2} \mathrm{OH}\right) \mathrm{C}(\mathrm{O}) \mathrm{C}_{6} \mathrm{H}_{5} ;{ }^{;[9]}$
53: $\mathrm{R}=t-\mathrm{Bu}, \mathrm{X}=\mathrm{N}\left(\mathrm{CH}_{2} \mathrm{CH}_{2} \mathrm{OH}\right) \mathrm{C}(\mathrm{O}) \mathrm{CH}_{3} ;{ }^{; 49]}$

54: $\mathrm{R}=t-\mathrm{Bu}, \mathrm{X}=\mathrm{N}\left(\mathrm{CH}_{2} \mathrm{CH}_{2} \mathrm{OH}\right) \mathrm{C}(\mathrm{O}) \mathrm{C}_{2} \mathrm{H}_{5},{ }^{[49]}$

55: $\mathrm{R}=t-\mathrm{Bu} ; \mathrm{X}=\mathrm{NHNH}_{2} ;{ }^{[50-52]}$

56: $\mathrm{R}=\mathrm{H} ; \mathrm{X}=\mathrm{NHNH}_{2}$; ${ }^{[53]}$

57: $\mathrm{R}=t-\mathrm{Bu} ; \mathrm{X}=\mathrm{H}_{\mathrm{H}}^{-\mathrm{N}}$

58: $\mathrm{R}=t-\mathrm{Bu} ; \mathrm{X}=\stackrel{-\mathrm{H}}{\mathrm{H}} \mathrm{O}^{\mathrm{N}}$

59: $\mathrm{R}=t-\mathrm{Bu} ; \mathrm{X}=\stackrel{-}{\mathrm{H}}$

60: $\mathrm{R}=t-\mathrm{Bu} ; \mathrm{X}=\stackrel{-\mathrm{N}-\mathrm{N}}{\mathrm{H}}$

61: $\mathrm{R}=t-\mathrm{Bu} ; \mathrm{X}=\mathrm{NHNHC}_{6} \mathrm{H}_{5} ;{ }^{[54]}$

62: $\mathrm{R}=t-\mathrm{Bu} ; \mathrm{X}=\stackrel{\mathrm{N}}{\mathrm{N}}$

63: $\mathrm{R}=t-\mathrm{Bu} ; \mathrm{X}={ }_{\mathrm{H}}^{\mathrm{N}}-\mathrm{N}_{;}^{\mathrm{N}}$

64: $\mathrm{R}=t-\mathrm{Bu} ; \mathrm{X}={ }_{\mathrm{H}}^{-\mathrm{N}}$

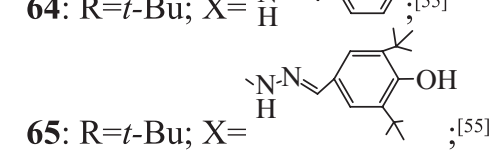

66: $\mathrm{R}=\mathrm{H} ; \mathrm{X}=$

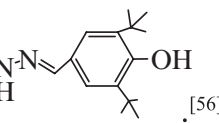

Scheme 2. 


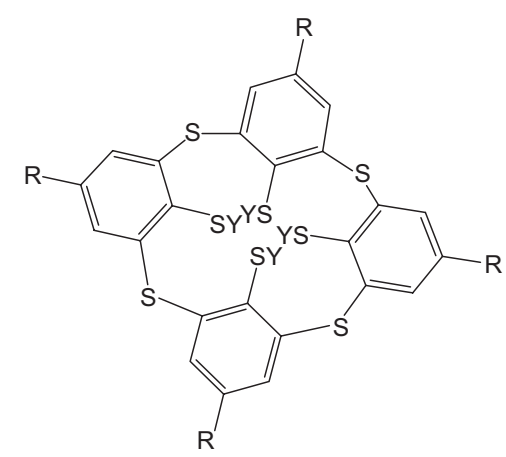

67: $\mathrm{R}=t-\mathrm{Bu} ; \mathrm{Y}=\mathrm{H} ;{ }^{[57]}$

68: $\mathrm{R}=t-\mathrm{Bu} ; \mathrm{Y}=\left(\mathrm{CH}_{2}\right)_{\mathrm{n}}$-Pyrazolyl, $\mathrm{n}=2-4,1,3$-alternate $;{ }^{[31]}$

69: $\mathrm{R}=t-\mathrm{Bu} ; \mathrm{Y}=\left(\mathrm{CH}_{2}\right)_{3} \mathrm{CN}, 1,3$-alternate $;{ }^{[59]}$

70: $\mathrm{R}=t$-Bu; $\mathrm{Y}=\mathrm{CH}_{2} \mathrm{C}_{6} \mathrm{H}_{4} \mathrm{CN}, 1,3$-alternate ${ }^{[59]}$

71: $\mathrm{R}=t-\mathrm{Bu} ; \mathrm{Y}=\left(\mathrm{CH}_{2} \mathrm{Py}(\alpha, \beta, \gamma), 1,3\right.$-alternate. ${ }^{[60]}$

Scheme 3.

bearing two pairs of different substituents on opposite sides of the thiacalix[4]arene scaffold are of great interest for the design very sophisticated and advanced supramolecular architectures. Such macrocycles allow to create within a single molecule two spatially separated molecular domains with quite different properties, for example, hydrophilic and hydrophobic, receptor and indicator, etc. The basic approach to the synthesis of these compounds is stepwise functionalization of the macrocycle according to Figure 3.

The first stage is a preparation of distal disubstituted compounds in the cone conformation. Unlike to classical calix[4]arenes a synthesis of partially substituted thiacalixarenes is a rather sophisticated problem. The different behavior of these macrocycles is due to energy changes of intramolecular circular hydrogen bonds: 26-28 and 20-21 $\mathrm{kcal} \cdot \mathrm{mol}^{-1}$ for calix[4] arenes and thiacalix[4]arenes, respectively, ${ }^{[16,17]}$ and acid-base properties of phenolic groups. ${ }^{[61]}$ In fact, distal disubstituted derivatives can be selectively synthesized using the appropriate reaction conditions for a given substituent. The most often used conditions are stoichiometric amounts of reagents and base, the presence water in the solvent, a reaction time, a solvent in which the intermediates are removed from the reaction zone due to their low solubility. Thus, a number of distal substituted derivatives were obtained in the yields of 50-85\% (Scheme 4, compounds 72-77).

The second synthetic way to stop etherification at the intermediate stage is creation of steric hindrance at the reaction sites during functionalization using bulky reagents. This approach has been successfully implemented by Bitter

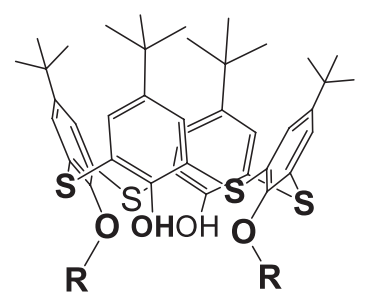
72: $\mathrm{R}=\mathrm{CH}_{3},{ }^{[62]}$
73: $\mathrm{R}=\mathrm{CH}_{2} \mathrm{COOEt} ;{ }^{[63]}$
74: $\mathrm{R}=\mathrm{CH}_{2} \mathrm{COOH} ;{ }^{[63]}$
75: $\left.\mathrm{R}=\mathrm{CH}_{2} \mathrm{C}_{6} \mathrm{H}_{5}, ; 64\right]$
76: $\mathrm{R}=\mathrm{CH}_{2} \mathrm{CN}$; ${ }^{[65]}$
77: $\mathrm{R}=\mathrm{CH}_{2} \mathrm{CONHC}_{6} \mathrm{H}_{4} \mathrm{NO}_{2} ;$;66]
78: $\mathrm{R}=\left(\mathrm{CH}_{2}\right)_{\mathrm{n}} \mathrm{Y} ;{ }^{[67]}$
79: $\mathrm{R}=\left(\mathrm{CH}_{2}\right)_{\mathrm{n}} \mathrm{CH}_{3}(\mathrm{n}=3,7,13) ;{ }^{[68]}$
80: $\mathrm{R}=\left(\mathrm{CH}_{2}\right)_{2} \mathrm{SMe}$; ${ }^{[69]}$
81: $\mathrm{R}=\left(\mathrm{CH}_{2}\right)_{2} \mathrm{SBz} ;{ }^{[69]}$
82: $\mathrm{R}=\left(\mathrm{CH}_{2}\right)_{3} \mathrm{Set} ;{ }^{[69]}$
83: $\mathrm{R}=$ diynyl $=\mathrm{CH}_{2} \mathrm{C} \equiv \mathrm{C}-\mathrm{C} \equiv \mathrm{C}-\mathrm{C}_{6} \mathrm{H}_{5},{ }^{; 70]}$
84: $\mathrm{R}=\mathrm{CH}_{2} \mathrm{COC}_{6} \mathrm{H}_{5} ;$;
85: $\mathrm{R}=\mathrm{C}_{3} \mathrm{H}_{7} \cdot{ }^{[71]}$

Scheme 4.

et al. ${ }^{[67]}$ Regioselective distal dialkylation of $\mathbf{1}$ was done with primary alcohols under the Mitsunobu protocol using diethyl azodicarboxylate/triphenylphosphine (DEAD/TPP) system. In these conditions the lower rim functionalization stopped at the disubstitution stage. This approach was successfully applied for the synthesis of a series of distal thiacalix[4]arenes $\mathbf{7 8 - 8 3}$ adopting a cone conformation in the yields from 29 to $89 \%$ (Scheme 4).

Unlike to distal derivatives of conventional calix[4]arenes those of thiacalix[4]arenes are very unstable at the alkaline conditions. It was shown that they are hydrolyzed to the parent macrocycles in the presence of rather weak bases (such as amines). In particular, the phenacyl moiety can be easily and quantitatively removed from the thiacalixarene platform by either heating in DMF in the presence of a base (sodium carbonate) or refluxing in toluene or benzene in the presence of benzylamine or hexylamine (Scheme 5) ${ }^{[71]}$ Really, it is a big problem for further macrocycle modification.

Moreover, the attempt to perform the functionalization at the remaining two phenol groups of macrocycle 84 with the aim to obtain a bifunctional tetrasubstituted product gave unexpected result (Scheme 6). ${ }^{[71]}$ The reaction of compound 84 with 1-iodopropane in acetone in the presence of sodium carbonate afforded distal dipropoxy derivative $\mathbf{8 5}$, in $89 \%$
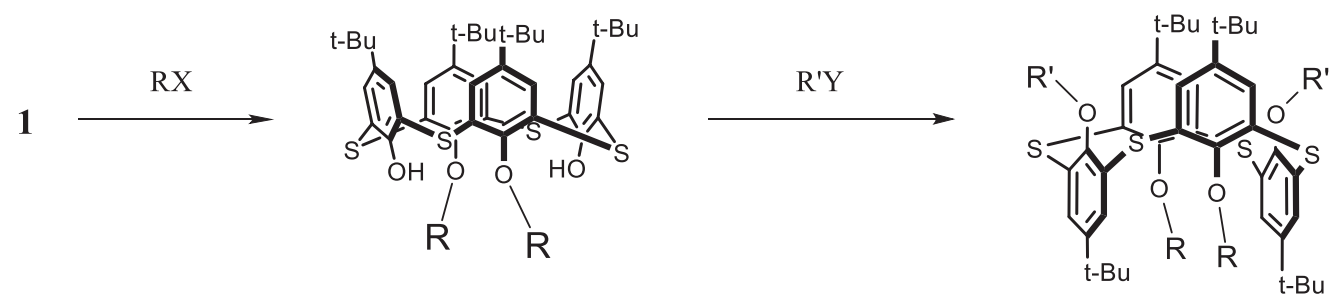

Figure 3. The strategy for obtaining thiacalix[4]arene bifunctional derivatives via Mitsunobu protocol. 


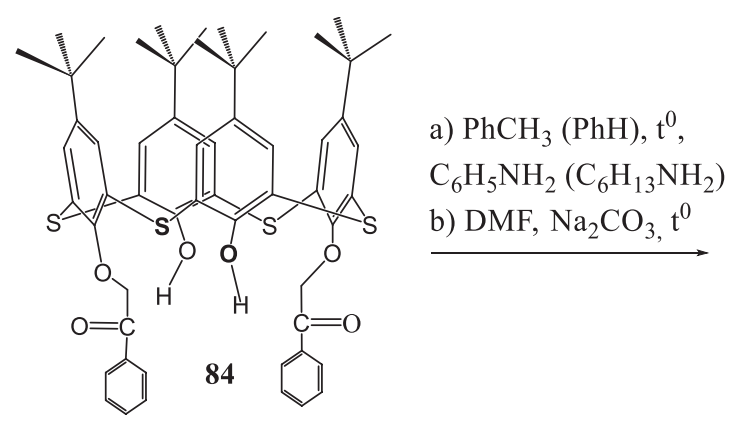

Scheme 5.

yield, or distal substituted by different substituents $\mathbf{8 6}$ in 75 $\%$ yield in the case of 1-bromopropan. It is the first example of the transalkylation reaction on thiacalixarene platform at the mild conditions.

The most possible mechanism of the transalkylation reaction is presented on the Scheme 7. The initially formed oxonium cation $\mathbf{8 7}$ is subjected to the nucleophilic attack at the $\mathrm{C}_{\alpha}$ atom of the phenacyl substituent because it is more electrophilic $\left(\delta_{1}^{+}>\delta_{2}^{+}\right)$compared to the $\mathrm{C}_{\alpha}$ atom of the alkyl group due to the electron-withdrawing character of the adjacent benzoyl substituent (Scheme 7).

The differences in the chemical behavior of the distal derivatives of calixarene and thiacalixarene can be explained by their structure features. X-ray data in the solid phase presented on Figure 4a-d clearly demonstrate significant differences of the spatial structure of these compounds. The distal thiacalixarene derivatives (Figure 4a,b) lose the symmetry $\mathrm{C}_{2}$ and adopt the distorted cone (DC) conformation $\left(\mathrm{C}_{\mathrm{s}}\right.$ symmetry) because two opposite benzene rings are bent not in the opposite directions, as it is observed in the classical cone conformation, but in the same direction, and are almost parallel to each other. One of the oxygen atoms is directed inside of the molecule while the second one - outside. In this case the free phenolic groups form hydrogen bonds only with one of the oxygen atoms located inside the cavity.

This pattern is fundamentally different from the classical disubstituted calixarenes (Figure 4c,d). ${ }^{[72-74]}$ The aromatic rings form a cup-shaped structure with $\mathrm{C}_{2 \mathrm{v}}$ symmetry (so called, pinched cone $\mathrm{PC}$ conformer) where each free phenolic group interacts only with one of the adjacent oxygen atom of substituted aryl moieties (Figure 4c,d). There are many examples of similar structures in the Cambridge Structural Database: distally disubstituted p-tert-butylthiacalix[4]arenes containing substituents with different electronic and steric characteristics, such as methyl, ${ }^{[75]}$ propyl, ${ }^{[71]}$ butyl, ${ }^{[68]}$ allyl, ${ }^{[76]}$ phenacyl, ${ }^{[71]}$ diethers $\mathrm{CH}_{2} \mathrm{COEt}$ with- and without tert-butyl grous on the upper rim, ${ }^{[77]}$ cyanomethxy ${ }^{[78]}$ as well as monocrown, ${ }^{[79]}$ bisporphyrin, ${ }^{[80]}$ biscalixarene ${ }^{[81]}$ and disubsituted with different substituents macrocycle 86. ${ }^{[71]}$

The differences in the spatial structure of disubstituted methylene and sulfur bridged macrocycle are also observed in the solution (Figure 5). ${ }^{[82]}$ Quantum chemical and dynamic NMR methods established that pinched cone (PC) and distorted cone (DC) conformations correspond to the energy minima on the potential energy surface. Moreover, in the $\mathrm{DC}$ form, two different mutual orientations of $\mathrm{O}-\mathrm{R}$ groups lead to two stable conformations: in the first one $\left(\mathrm{DC}_{1}\right)$, these $\mathrm{O}-\mathrm{R}$ groups are directed outward; in the second $\left(\mathrm{DC}_{2}\right)$, these groups are directed to one side. In the classical calix[4]arenes CCA, the PC form is essentially favored (by $3-4 \mathrm{kcal} \cdot \mathrm{mol}^{-1}$ ) versus the DC, while in the thiacalix[4]arenes TCA, energies of these forms are close or even the latter is preferable.

In this context, a possible reason for the acceleration of Ar-O-C ether bonds hydrolysis of distal thiacalixarene

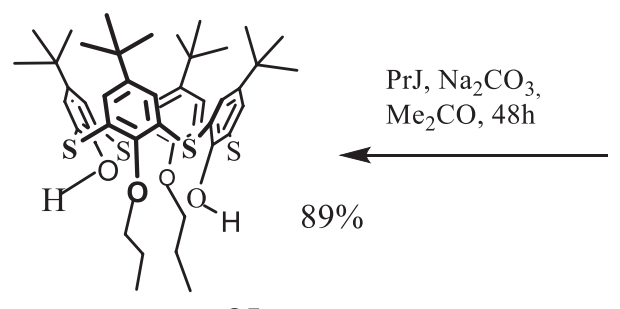

85

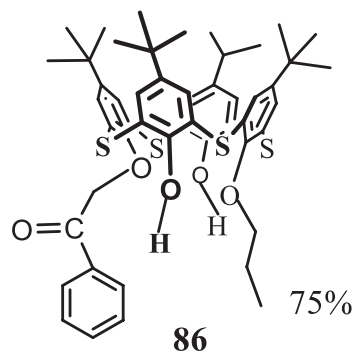

86

Scheme 6.

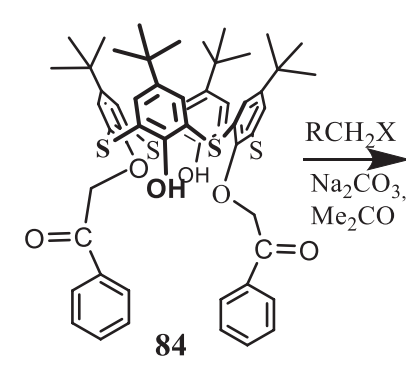

84

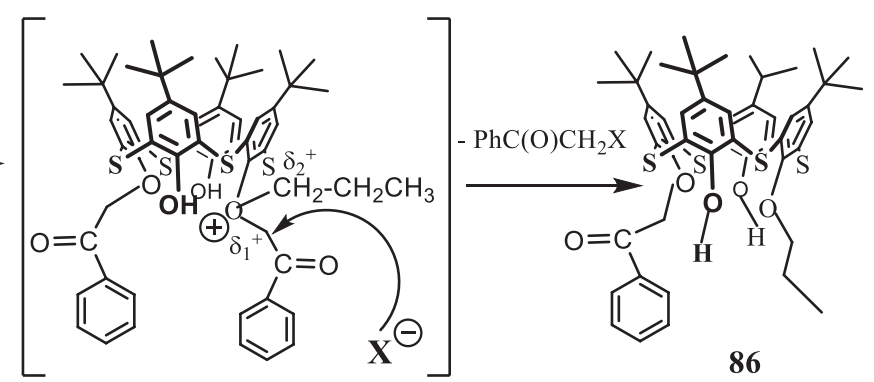

87 


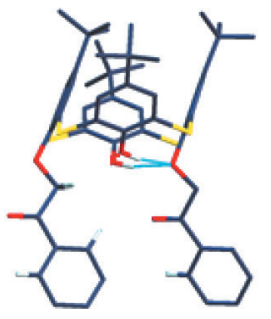

a

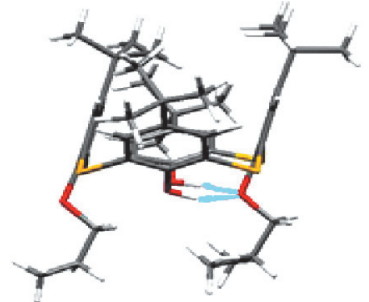

b

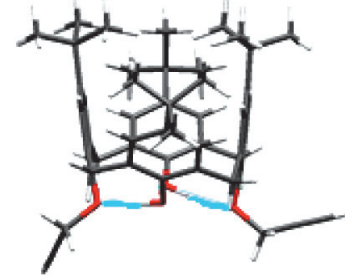

c

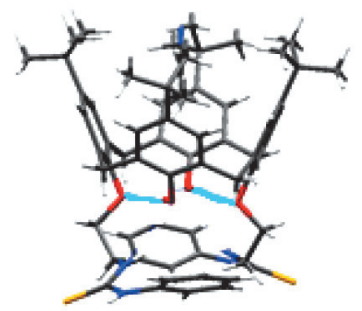

d

Figure 4. The structure of distal derivatives of thiacalix[4]arene $(\mathrm{a}, \mathrm{b})^{[71]}$ and calix[4]arene $\left(\mathrm{c}^{[72]}, \mathrm{d}^{[73]}\right)$ according to X-ray data (blue dotted lines indicate hydrogen bonds).

(Figure 6a) can be stabilization of leaving anionic group (Figure 6b) due to two intramolecular hydrogen bonds between oxy-anionic center and the two adjacent phenolic groups. It becomes clear why classical disubstituted calixarene (Figure 6c) derivatives are more stable to hydrolysis reactions: only one hydroxyl group is involved in a leaving group (Figure 6d) stabilization.
The functionalization of distal thiacalixarenes by biselectrophilic reagents at the similar conditions leads to the formation of the macrocycles with conformationally rigid structural blocks to construct more selective macrocyclic structures. In particularly, series of the calixcrown 88-98 containing different groups on opposite side of macrocycle were synthesized (Scheme 8).

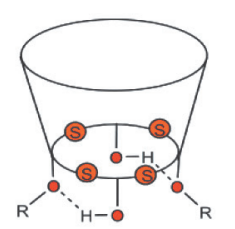

PC

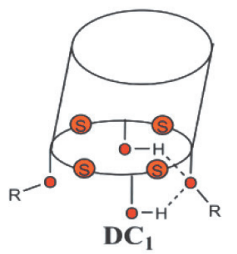

DC $_{1}$
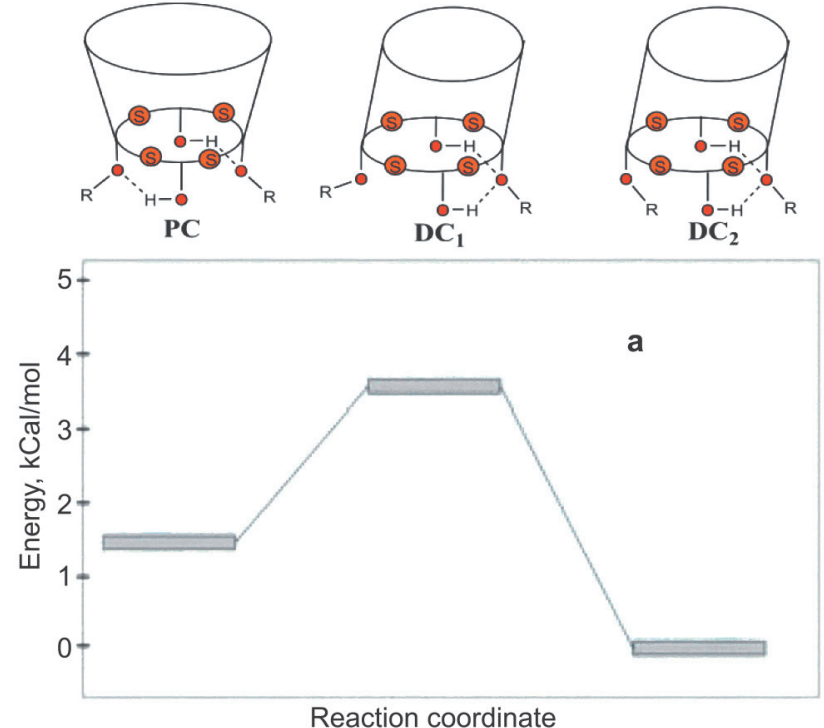

Reaction coordinate

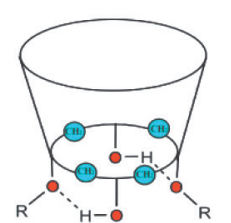

PC

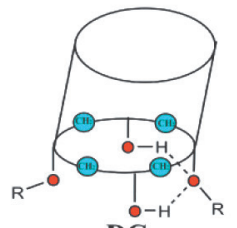

$\mathrm{DC}_{1}$
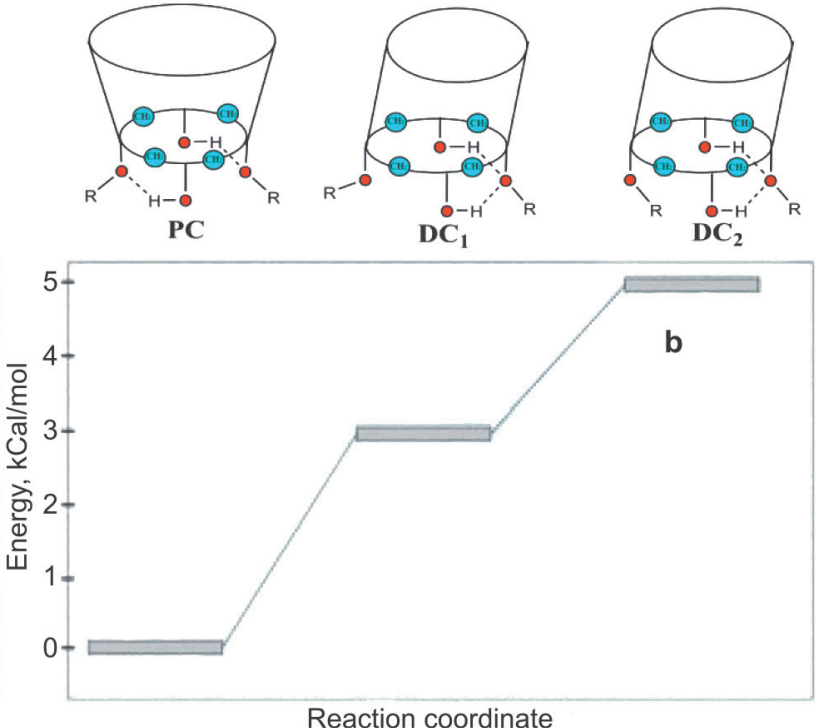

Figure 5. Schematical representation of energy diagrams for the main cone conformations of disubstituted thiacalix[4]arene TCA (a) and calix[4]arene CCA (b) derivatives.

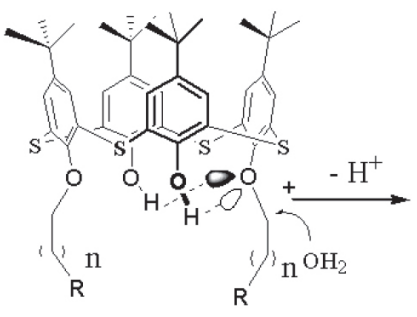

$\mathbf{a}$

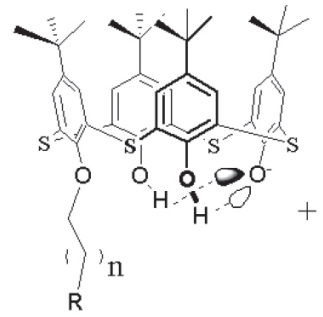

b

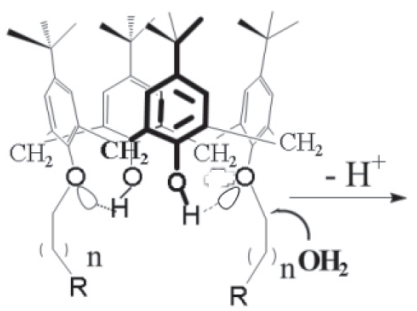

c

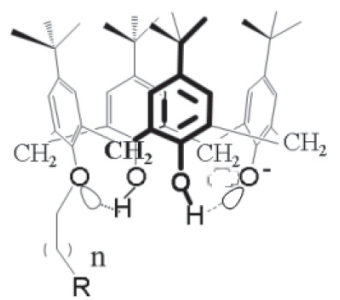

d

Figure 6. Possible reason for the acceleration of Ar-O-C ether bonds hydrolysis in the distal disubstituted thiacalixarene (a, b) and hydrolytic stability of calixarene (c, d). 


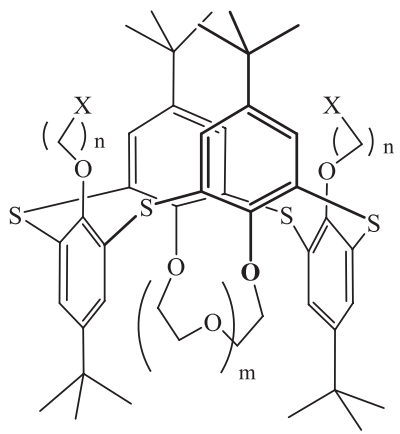

88: $\mathrm{X}=\mathrm{SMe}, \mathrm{m}=1,2, \mathrm{n}=1 ;{ }^{[69]}$

89: $\mathrm{X}=\mathrm{SBz}, \mathrm{m}=1,2, \mathrm{n}=1 ;{ }^{[69]}$

90: $\mathrm{X}=\mathrm{SEt}, \mathrm{m}=1,2, \mathrm{n}=2 ;{ }^{[69]}$

91: $\mathrm{X}=\mathrm{Br}, \mathrm{m}=1, \mathrm{n}=1,2 ;{ }^{[83]}$

92: $\mathrm{X}=\mathrm{SCOCH}_{3}, \mathrm{~m}=1, \mathrm{n}=2 ;{ }^{[83]}$

93: $\mathrm{X}=\mathrm{SH}, \mathrm{m}=1, \mathrm{n}=2$; $^{[83]}$

94: $\mathrm{X}=\mathrm{Br}, \mathrm{m}=2, \mathrm{n}=1,2 ;{ }^{[84]}$

95: $\mathrm{X}=\mathrm{Br}, \mathrm{m}=3, \mathrm{n}=1,2 ;{ }^{[84]}$

96: $\mathrm{X}=\mathrm{SAc}, \mathrm{m}=1,2,3, \mathrm{n}=1,2 ;{ }^{[85]}$

97: $\mathrm{X}=\mathrm{SAc}, \mathrm{m}=1,2,3, \mathrm{n}=1,2 ;{ }^{[85]}$

98: $\mathrm{X}=\mathrm{O}-$ ter $-\mathrm{Py}, \mathrm{m}=3,4, \mathrm{n}=3$. ${ }^{[86]}$

Scheme 8.

For the above-mentioned reasons a more efficient way for further modification of disubstituted thiacalix[4]-arene derivatives into bifunctional tetrasubstituted ones is a Mitsunobu reaction, in which strong bases are not used. So, the original approach was developed for the design of new type of amphiphilic compound based on bifunctional thiacalixarenes in 1,3-alternate stereoisomeric form. ${ }^{[68,70,87,88]}$ Selective functionalization of the macrocycle lower rim creates two molecular domains with quite different properties located on opposite sides of the macrocycles central plane. One of them has lipophilic properties due to the introduction of long chain alkyl substituents. The other side of the macrocycle contains the polar binding sites, which are easily introduced by CuAAC click reactions (Scheme 9a). Usually calixarene amphiphiles were synthesized in cone stereoisomeric form ${ }^{[89,90]}$ (Scheme 9b,c) using both lower and upper rims functionalization. But in the case of 1,3-alternate only lower rim modification is required that is more easy than upper rim one.

To achieve a wide variety of binding sites as well as amphiphilic properties, the 'clickable' platforms based on the azido or alkynyl derivatives of $p$-tert-butylthiacalix[4]arene were synthesized keeping in mind that the presence of azido group or triple bond provides an easy way to a number of amphiphilic receptor molecules by CuAAC click reaction (Scheme 10). Functionalization of two free phenolic groups by $\omega$-azidoalcohols or alcohols with terminal triple bond leads to the formation of desired azide/alkyne derivatives of thiacalixarene 99, 102-104. The corresponding azidoderivatives can be also synthesized by two-step modification comprising bromalkylation by $\omega$-bromoalcohols and subsequent reaction with sodium azide. Moreover, the stereoselective synthesis of photopolymerisable amphiphilic compound containing long chain 1,3-alkadiynyl substituents 105, 110-113 was done using analogous synthetic strategy.

\section{Supramolecular Properties of Thiacalix[4]arene Derivatives}

The creation of the nanoscale objects through the self-assembly of small molecules is an attractive strategy that brings with it the challenge of controlling the size and structure of the assemblies through interactions at the molecular level. Traditionally, synthetic amphiphiles have been designed to contain nonpolar parts that interact unfavorably with water together with polar subunits that interact favorably with water. However, it is more interesting when the aggregates are formed by amphiphilic synthetic receptors. They can provide functional nanoscale surfaces that can bind to specific guests, thus allowing further noncovalent modification. Moreover, such amphiphilic synthetic receptors can be used as a parts of multifunctional phospholipid vesicles, which attract a considerable interest due to their use in molecular recognition, drug delivery, cell mimics, catalysis and many other applications..$^{[1-6]}$

The compounds synthesized in our scientific group were used to study the supramolecular properties of the thiacalix[4]arenes as shown on the Figure 7. As part of this review, we will focus on one of them - self-assembly on the interfaces and their application for sensor design.

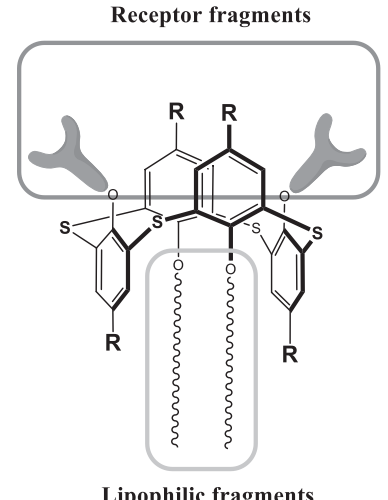

a

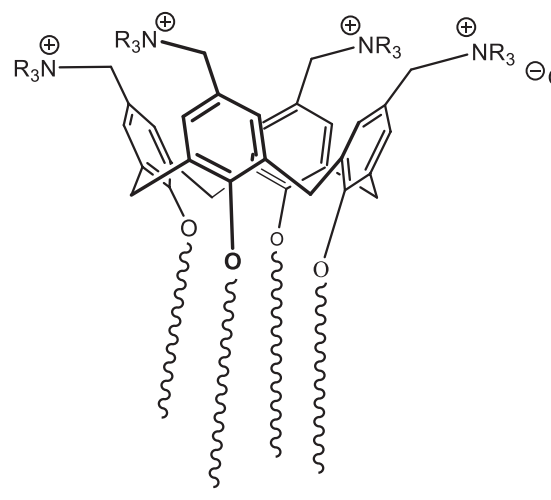

b

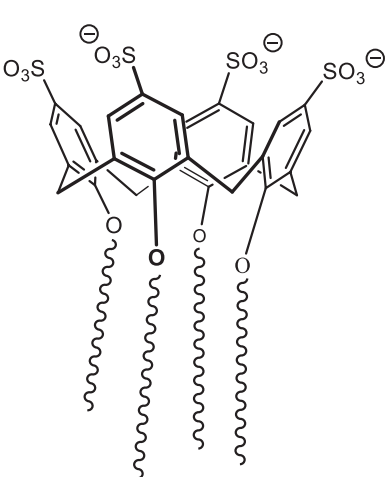

c

Scheme 9. 


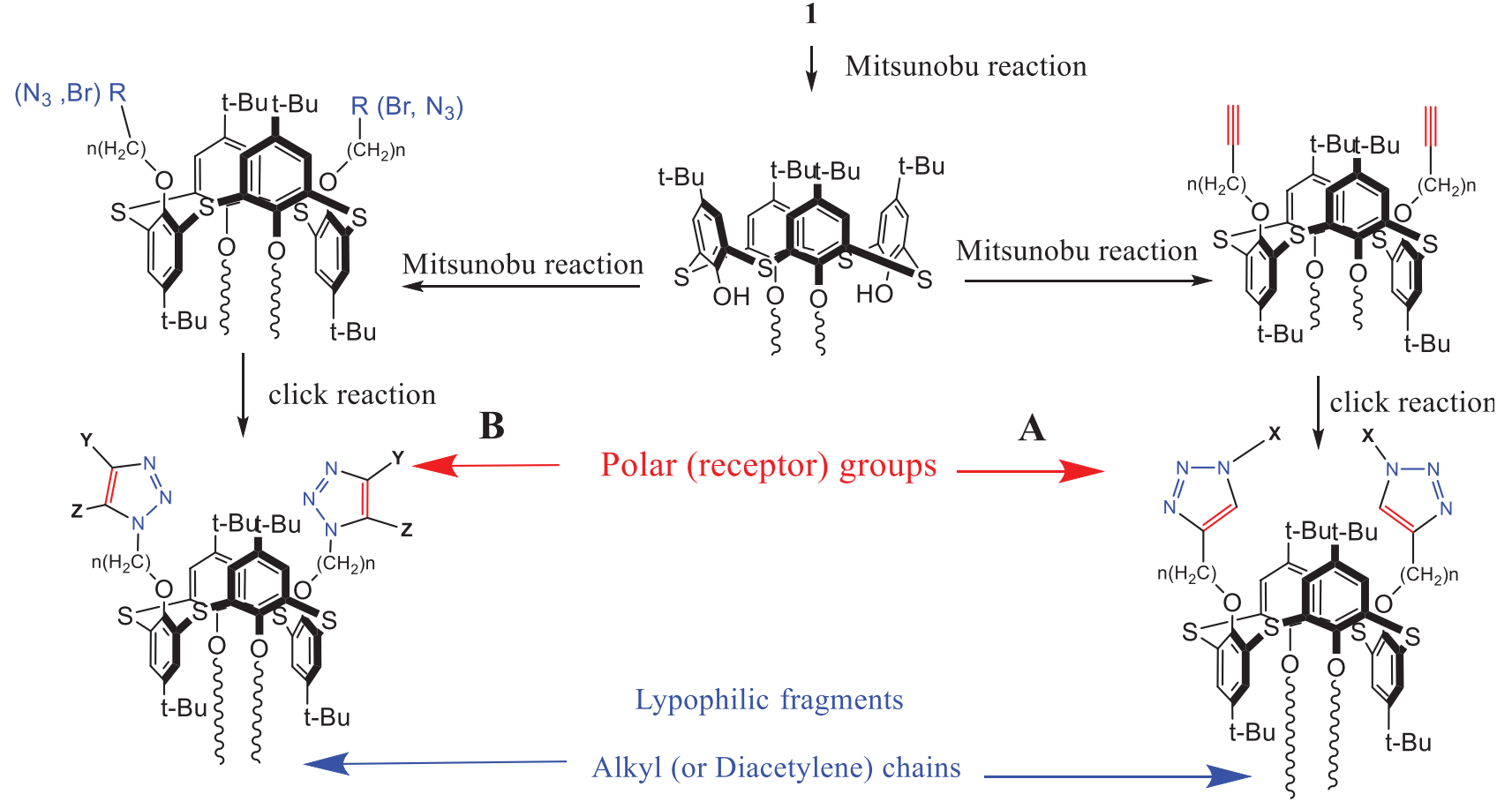

100: $\mathrm{R}^{\prime}=\left(\mathrm{CH}_{2}\right)_{3} \mathrm{Br}, \mathrm{Alk}=\mathrm{C}_{14} \mathrm{H}_{29} \cdot{ }^{[87]}$

101: $\mathrm{R}^{\prime}=\left(\mathrm{CH}_{2}\right)_{2} \mathrm{Br}, \mathrm{Alk}=\mathrm{C}_{14} \mathrm{H}_{29} \cdot{ }^{[87]}$

102: $\mathrm{R}^{\prime}=\left(\mathrm{CH}_{2}\right)_{3} \mathrm{~N}_{3}, \mathrm{Alk}=\mathrm{C}_{14} \mathrm{H}_{29} \cdot{ }^{[87]}$

103: $\mathrm{R}^{\prime}=\left(\mathrm{CH}_{2}\right)_{2} \mathrm{~N}_{3}, \mathrm{Alk}=\mathrm{C}_{14} \mathrm{H}_{29} \cdot{ }^{[87]}$

104: $\mathrm{R}^{\prime}=\left(\mathrm{CH}_{2}\right)_{3} \mathrm{~N}_{3}, \mathrm{Alk}=\mathrm{C}_{4} \mathrm{H}_{9}, \mathrm{C}_{8} \mathrm{H}_{17}, \mathrm{C}_{14} \mathrm{H}_{29}{ }^{\cdot[88]}$

105: $\mathrm{R}^{\prime}=\left(\mathrm{CH}_{2}\right)_{3} \mathrm{~N}_{3}$, Diynyl $\left.=\mathrm{CH}_{2} \mathrm{C} \equiv \mathrm{C}-\mathrm{C} \equiv \mathrm{C}-\mathrm{C}_{6} \mathrm{H}_{5}, ; 70\right]$

B:

106: $\mathrm{n}=3$; $\mathrm{Y}=\mathrm{COOH}, \mathrm{Z}=\mathrm{COOH}, \mathrm{Alk}=\mathrm{C}_{4} \mathrm{H}_{9}, \mathrm{C}_{8} \mathrm{H}_{17}, \mathrm{C}_{14} \mathrm{H}_{29} \cdot{ }^{[87]}$

107: $\mathrm{n}=3 ; \mathrm{Y}=\mathrm{CH}_{2} \mathrm{NH}_{2}, \mathrm{Z}=\mathrm{H}, \mathrm{Alk}=\mathrm{C}_{14} \mathrm{H}_{29} ;{ }^{[87]}$

108: $\mathrm{n}=3 ; \mathrm{Y}=\mathrm{CH}_{2} \mathrm{OH}, \mathrm{Z}=\mathrm{H}, \mathrm{Alk}=\mathrm{C}_{14} \mathrm{H}_{29} ;{ }^{[87]}$

109: $\mathrm{n}=3 ; \mathrm{Y}=\mathrm{CH}_{2} \mathrm{~N}^{+}(\mathrm{Et}){ }_{3} \mathrm{Br}, \mathrm{Z}=\mathrm{H}, \mathrm{Alk}=\mathrm{C}_{4} \mathrm{H}_{9}, \mathrm{C}_{8} \mathrm{H}_{17}, \mathrm{C}_{14} \mathrm{H}_{29} \cdot{ }^{[88]}$

110: $\mathrm{n}=3 ; \mathrm{Y}=\mathrm{CH}_{2} \mathrm{C}_{6} \mathrm{H}_{5}, \mathrm{Z}=\mathrm{H}$, Diynyl $=\mathrm{CH}_{2} \mathrm{C} \equiv \mathrm{C}-\mathrm{C} \equiv \mathrm{C}-\mathrm{C}_{6} \mathrm{H}_{5} ;{ }^{; 70]}$

111: $\mathrm{n}=3 ; \mathrm{Y}=\mathrm{CH}_{2} \mathrm{NH}_{2}, \mathrm{Z}=\mathrm{H}$, Diynyl $=\mathrm{CH}_{2} \mathrm{C} \equiv \mathrm{C}-\mathrm{C} \equiv \mathrm{C}-\mathrm{C}_{6} \mathrm{H}_{5} ;{ }^{; 70]}$

112: $\mathrm{n}=3 ; \mathrm{Y}=\mathrm{COOH}, \mathrm{Z}=\mathrm{COOH}$, Diynyl $=\mathrm{C}_{2} \mathrm{C} \equiv \mathrm{C}-\mathrm{C} \equiv \mathrm{C}-\mathrm{C}_{6} \mathrm{H}_{5} ;{ }^{[70]}$

113: $\mathrm{n}=3 ; \mathrm{Y}=$ phtalimide, $\mathrm{Z}=\mathrm{H}$, Diynyl $=\mathrm{CH}_{2} \mathrm{C} \equiv \mathrm{C}-\mathrm{C} \equiv \mathrm{C}-\mathrm{C}_{6} \mathrm{H}_{5},[70]$

114: $\mathrm{n}=3 ; \mathrm{Y}=\mathrm{CH}_{2} \mathrm{~N}\left[\left(\mathrm{CH}_{2}\right)_{2} \mathrm{NHBoc}\right]_{2}, \mathrm{Z}=\mathrm{H}, \mathrm{Alk}=\mathrm{C}_{4} \mathrm{H}_{9}, \mathrm{C}_{8} \mathrm{H}_{17}$, $\mathrm{C}_{14} \mathrm{H}_{29} \cdot{ }^{[91]}$

115: $\mathrm{n}=3 ; \mathrm{Y}=\mathrm{CH}_{2} \mathrm{~N}^{+} \mathrm{H}\left[\left(\mathrm{CH}_{2}\right)_{2} \mathrm{~N}^{+} \mathrm{H}_{3}\right]_{2} \mathrm{Cl}_{3}^{-}, \mathrm{Z}=\mathrm{H}$,

$\mathrm{Alk}=\mathrm{C}_{4} \mathrm{H}_{9}, \mathrm{C}_{8} \mathrm{H}_{17}, \mathrm{C}_{14} \mathrm{H}_{29} ;[$; 91$]$

116: $\mathrm{n}=3 ; \mathrm{Y}=\mathrm{CH}_{2} \mathrm{~N}^{+} \mathrm{Et}_{3} \mathrm{Br}, \mathrm{Z}=\mathrm{H}, \mathrm{Alk}=\mathrm{C}_{4} \mathrm{H}_{9}, \mathrm{C}_{8} \mathrm{H}_{17}, \mathrm{C}_{14} \mathrm{H}_{29}{ }^{\cdot[92]}$

Scheme 10.

\section{Self-Assembly on the Interfaces}

It was found that tetracyanopropoxy-p-tert-butylthiacalix[4]arene $\mathbf{1 0}$ in 1,3-alternate conformation forms a typical monomolecular layer with perpendicular orientation of the macrocycle relative to the water-air interface (Figure 8a). Moreover, it is able to immobilize cytochrome $c^{[93,94]}$ and the increase of effective molecular area from 1.11 up to 1.50 $\mathrm{nm}^{2}$ was observed (Figure $8 \mathrm{~b}$ ). Obtained monolayers were transferred by Langmuir-Schaefer technique onto quartz, indium-tin oxide (ITO) and silicon. AFM indicates that island type of the films is formed at the first steps of layer-by-layer deposition, but after five initial steps the island type tends to transform into the continuous film with approximately $1.5 \mathrm{~nm}$
99: Alkynyl=- $\mathrm{CH}_{2} \mathrm{C} \equiv \mathrm{CH}, \mathrm{Alk}=\mathrm{C}_{4} \mathrm{H}_{9}, \mathrm{C}_{8} \mathrm{H}_{17}, \mathrm{C}_{14} \mathrm{H}_{29}{ }^{\cdot[68]}$

A:

117: $\mathrm{n}=1 ; \mathrm{X}=\mathrm{Bn}, \mathrm{Alk}=\mathrm{C}_{4} \mathrm{H}_{9}, \mathrm{C}_{8} \mathrm{H}_{17}, \mathrm{C}_{14} \mathrm{H}_{29} ;{ }^{[68]}$

118: $\mathrm{n}=1 ; \mathrm{X}=p-\mathrm{NO}_{2} \mathrm{C}_{6} \mathrm{H}_{4}, \mathrm{Alk}=\mathrm{C}_{4} \mathrm{H}_{9}, \mathrm{C}_{8} \mathrm{H}_{17}, \mathrm{C}_{14} \mathrm{H}_{29} ;{ }^{[68]}$

119: $\mathrm{n}=1 ; \mathrm{X}=\mathrm{Bn}, \mathrm{Alk}=\mathrm{C}_{4} \mathrm{H}_{9}, \mathrm{C}_{8} \mathrm{H}_{17}, \mathrm{C}_{14} \mathrm{H}_{29} \cdot{ }^{[68]}$

120: $\mathrm{n}=1 ; \mathrm{X}=2,4,6$-trichlorophenyl, $\mathrm{Alk}=\mathrm{C}_{4} \mathrm{H}_{9} ;{ }^{[68]}$

121: $\mathrm{n}=1 ; \mathrm{X}=p-\mathrm{MeOC}_{6} \mathrm{H}_{4}, \mathrm{Alk}=\mathrm{C}_{4} \mathrm{H}_{9} ;[68]$

122: $\mathrm{n}=1 ; \mathrm{X}=\mathrm{CH}_{2} \mathrm{C}(\mathrm{O}) \mathrm{O}-\mathrm{t}-\mathrm{Bu}, \mathrm{Alk}=\mathrm{C}_{4} \mathrm{H}_{9} ;{ }^{[68]}$ 


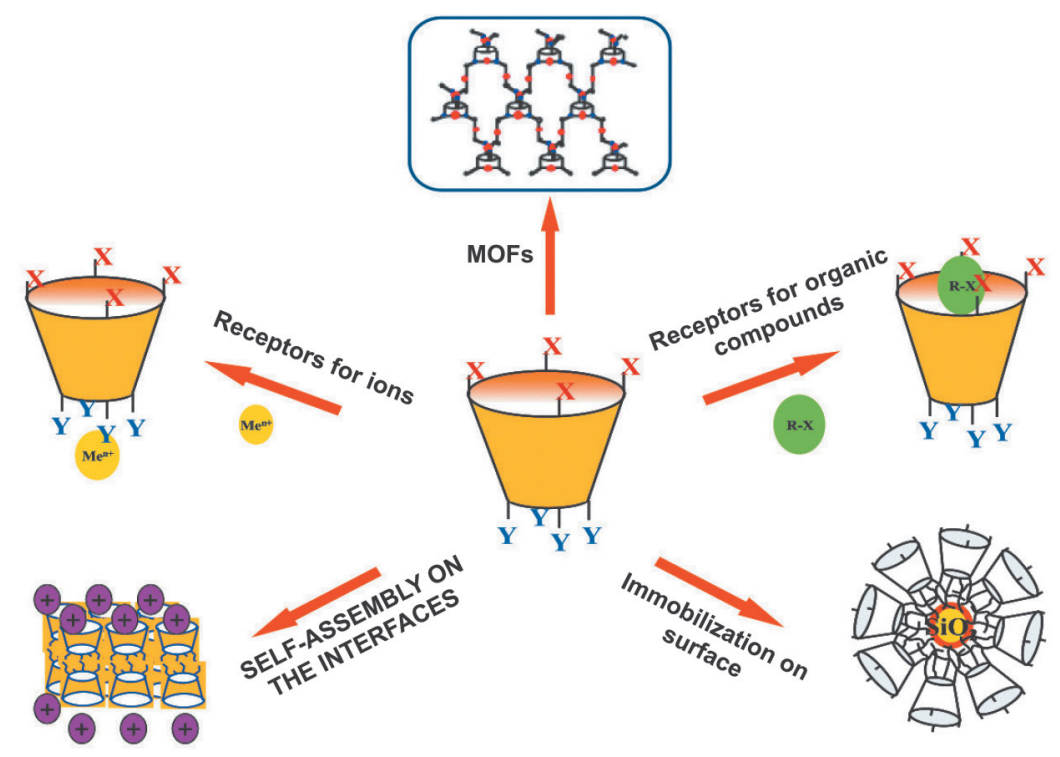

Figure 7. Supramolecular systems based on calixarenes: technological platform for nanomaterials design by self-assembly method.
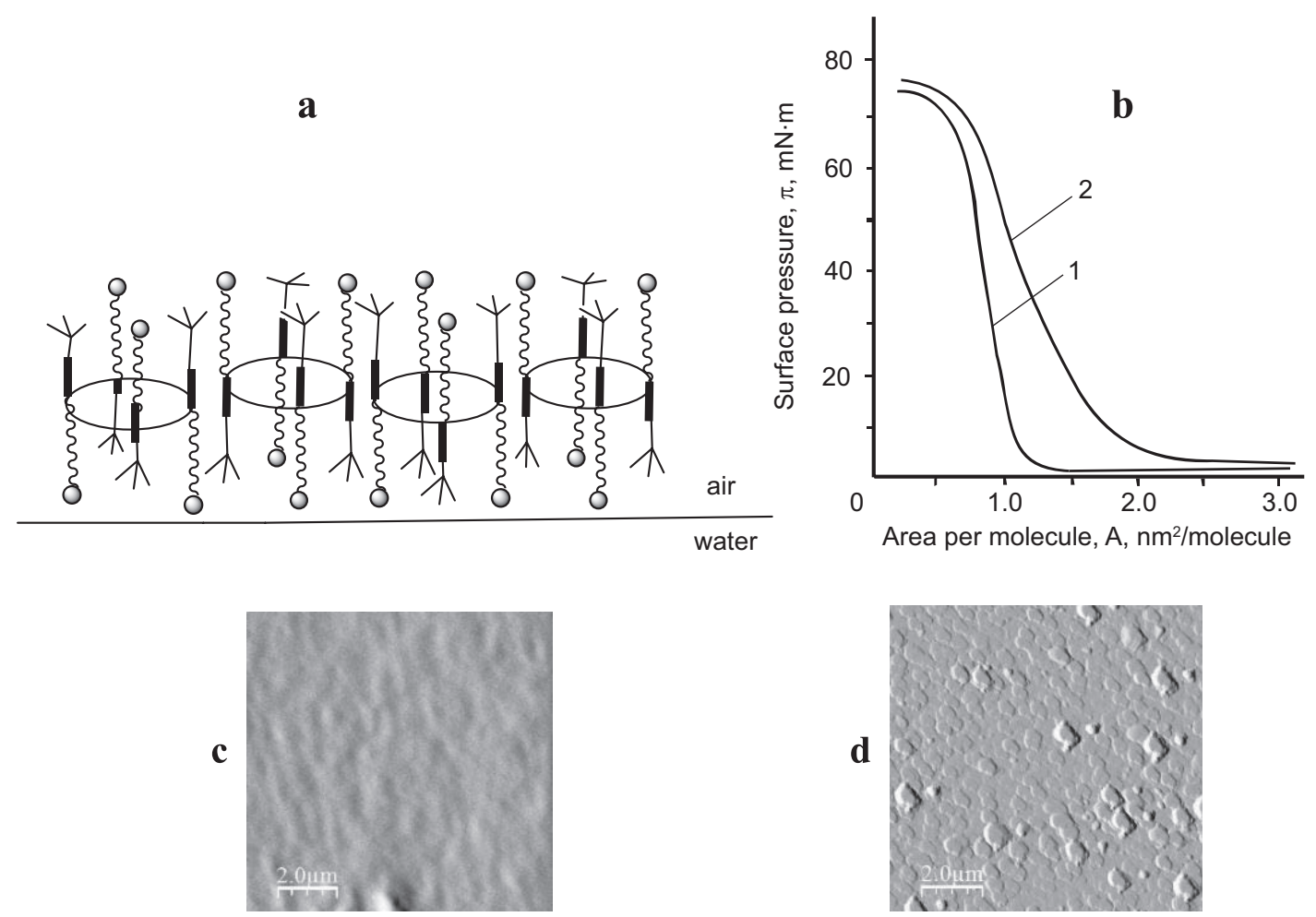

Figure 8. a) Schematic representation of macrocycle 10 monomolecular layer on the water-air interface; b) Compression isotherm of monolayers: 10 (curve 1); in the presence of cytochrome $c$ (curve 2); c) AFM images of 10-based films transferred from different subphases on ITO: 5 monolayers transferred from deionized water; d) 5 monolayers transferred from $10 \mathrm{mg} \cdot \mathrm{L}^{-1}$ aqueous solution of cyt $c$.

New type of ligands on the basis of thiacalix[4]arene platform in 1,3-alternate conformation was designed for gold surface functionalization. ${ }^{[85]}$ It contains crown-ether fragment for the binding of positively charged parts of biomolecules, on one side of macrocycle, and anchoring thioacetate groups for the immobilization on a solid substrate, on other side. Thiacalixcrown 97 ( $X=\mathrm{SAc}, \mathrm{m}=3$, $\mathrm{n}=2$ ) nanofilm improves adhesion between gold surface and biomolecules (cytochrome $c$ and catalase). Contact angle measurements and AFM visualization provide evidence of the formation of continuous film with immobilized biomolecules on the gold surface.

Amphiphilic tetracarboxylate derivatives 106- $\mathrm{C}_{4} \mathrm{H}_{9}$, 106- $\mathrm{C}_{8} \mathrm{H}_{17}$, 106- $\mathrm{C}_{14} \mathrm{H}_{29}{ }^{[95]}$ were embedded in dipalmatoilphosphoditylcholine (DPPC) vesicles using well-known film hydration method with further extrusion. Embedding of amphiphilic molecules into vesicle membrane leads to perturbation of lipid bilayer and to the phase transition temperature changes. According to our data ${ }^{[95]} 1 \% \mathrm{~mol}$ of calixarenes doesn't effect on the phase transition temperature, 
while $10 \%$ of calixarene has a great influence, especially in the case of octyl $\left(\mathbf{1 0 6}-\mathrm{C}_{8} \mathrm{H}_{17}\right)$ and tetradecyl $\left(\mathbf{1 0 6}-\mathrm{C}_{14} \mathrm{H}_{29}\right)$ derivatives. According to DLS data in all cases the size of vesicles is approximately $100 \mathrm{~nm}$.

It was found that calixarene-DPPC vesicles can act as an antenna for $\mathrm{Tb}$ (III) luminescence (Figure 9a). These luminescent vesicles were successfully used in fluorimetric detection of several biologically relevant analytes like sugars, aminoacids and nucleozidephosphates. Among them pyridoxine hydrochloride selectively quenches vesicles luminescence and luminescent response is significant even at $7 \mu \mathrm{mol}$ of pyridoxine. Moreover, luminescent response is unchanged in the presence of sugars, amino acids or nucleoside phosphates (Figure 9b). Thus, this system has good background for further use in analytical applications.

Amphiphilic derivatives with diyne substituents 111 and $\mathbf{1 1 2}$ were used as a dopant of polydiacetylene vesicles of 10,12-pentacosadiynoic acid (PCDA). ${ }^{[70]}$ Vesicles were prepared using film hydration method with $10 \%$ of calixarene 111 and $\mathbf{1 1 2}$ accompanied following filtration and polymerization under UV light. According to DLS data, the size of all investigated vesicles decreased after photopolymerization (Table 1). The role of dopant is well visible from measuring of $\zeta$ (dzeta)-potential: anionic calixarene leads to the increase of negative charge of vesicle while aminocalixarene decreases the surface charge and the formation of large aggregates is observed. TEM images ${ }^{[70]}$ of obtained nanoparticles are in good accordance with DLS - size and shape of carboxycalixarene-containing particles is similar to pure PCDA particles, while particles with aminocalixarene are in high aggregated form.

Study of the colorimetric response of polymerized vesicles containing calixarene $\mathbf{1 1 2}$ towards different metal cations showed a selective response to the lanthanides ions Gd(III), Dy(III) and Tb(III) that can be easily detected by naked eye. ${ }^{[70]}$ Other investigated ions: $\mathrm{K}(\mathrm{I}), \mathrm{Na}(\mathrm{I}), \mathrm{Ca}(\mathrm{II})$, $\mathrm{Sr}(\mathrm{II}), \mathrm{Ba}$ (II), $\mathrm{Hg}$ (II), $\mathrm{Cu}(\mathrm{II}), \mathrm{Pb}$ (II), $\mathrm{Zn}(\mathrm{II}), \mathrm{Ni}(\mathrm{II}), \mathrm{Fe}(\mathrm{II})$, $\mathrm{Fe}(\mathrm{III}), \mathrm{Co}(\mathrm{III})$, do not interact with PCDA-112 vesicles and do not change their color. The selective colorimetric response of polymerized vesicles containing calixarene $\mathbf{1 1 2}$ upon addition of lanthanide ions can be attributed with the deformation of calixarene backbone (allosteric systems) caused by the strong complexation of carboxylic groups with lanthanide ions on the one side of calixarene platform and corresponding distortion of PDA $\pi$-conjugated backbone on other side of macrocycle.

New water-soluble amphiphilic derivatives of $p$-tertbutylthiacalix[4]arene in 1,3-alternate stereoisomeric form with different length of $O$-alkyl chains 115, $116\left(\mathrm{C}_{4}, \mathrm{C}_{8}\right.$, $\mathrm{C}_{14}$ ) containing polycationic fragments were studied ${ }^{[91,92]}$ to discover efficient carries capable of compacting, protecting, transporting, and delivering nucleic acids and proteins into the cell. It is noteworthy that amphiphilic gene vectors based on calixarenes are presented only in cone stereoisomeric form, ${ }^{[89,90]}$ while 1,3-alternate also allows to achieve a spatial separation between hydrophilic and hydrophobic moieties of macrocycle. It was found that macrocycles $\mathbf{1 1 5}$ form aggregates at the micromolar concentration range (9-25 $\mu \mathrm{M})$ in aqueous solutions like amphiphilic calixarenes in cone conformation. The aggregate's diameter is within 50-100 $\mathrm{nm}$ and indicates on the formation of the vesiclelike structures. A significant size decrease up to $50-60 \mathrm{~nm}$ was observed in the case of $O, O$-ditetradecyl derivative and can be associated with increased packing density of the resulting vesicles by enhancing hydrophobic interactions between lipophilic molecule fragments. Also, $\zeta$-potentials
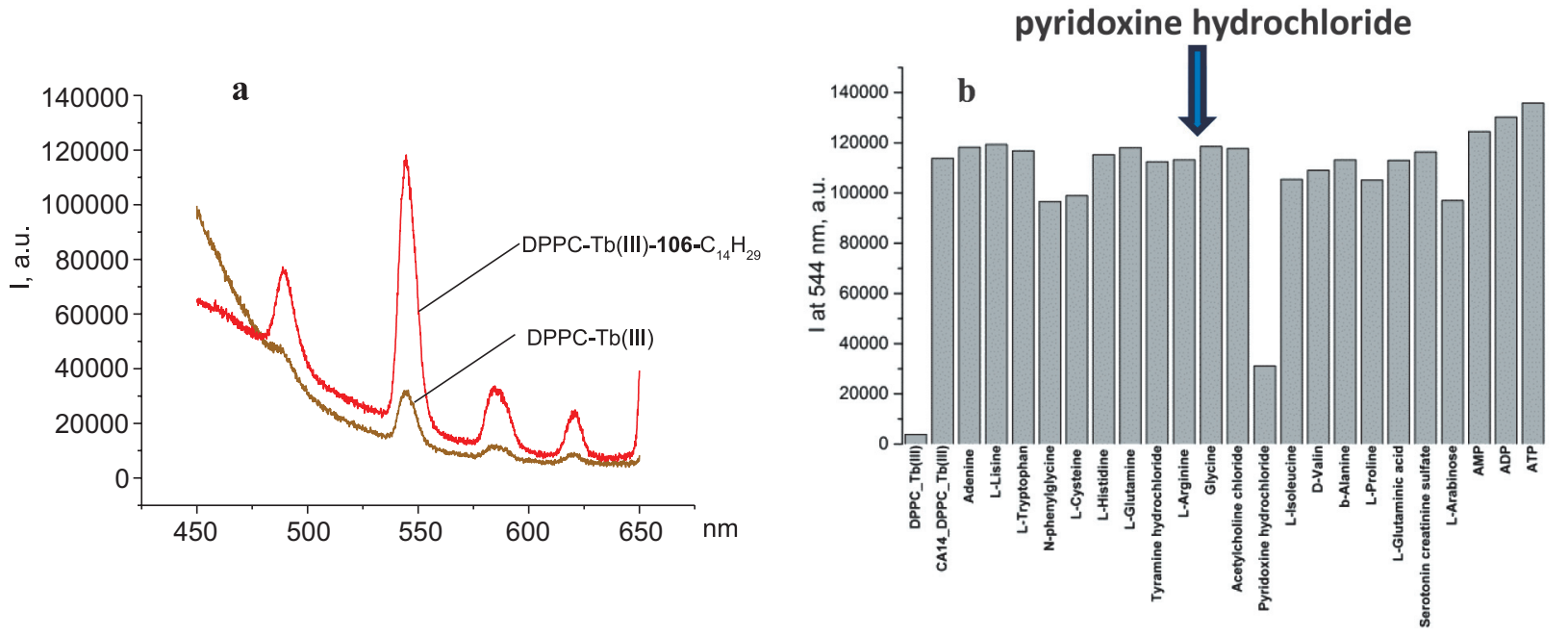

Figure 9. a) Luminescence of DPPC-106- $\mathrm{C}_{14} \mathrm{H}_{29}$ - $\mathrm{Tb}(\mathrm{III})$ and DPPC-Tb(III), $\mathrm{pH}=7.4$; b) DPPC-106- $\mathrm{C}_{14} \mathrm{H}_{29}$ - $\mathrm{Tb}$ (III) luminescence at $544 \mathrm{~nm}$ in the presence of different guests.

Table 1. DLS and $\xi$-potential data for PCDA-calixarene 111, 112 vesicles solution before and after UV polymerization.

\begin{tabular}{cccccc}
\hline Calixarene & $C_{\text {calix }}, \mathrm{mM}$ & $C_{\mathrm{PCDA}}, \mathrm{mM}$ & average D, nm & average D, nm & $\xi, \mathrm{mV}$ \\
\hline- & - & 0.2 & $217 \pm 1$ & $155 \pm 11$ & $-50 \pm 1$ \\
$\mathbf{1 1 1}$ & 0.02 & 0.2 & $215 \pm 3$ & $129 \pm 2$ & $-62 \pm 4$ \\
$\mathbf{1 1 2}$ & 0.02 & 0.2 & $1719 \pm 90$ & $1032 \pm 55$ & $-37 \pm 4$ \\
\hline
\end{tabular}



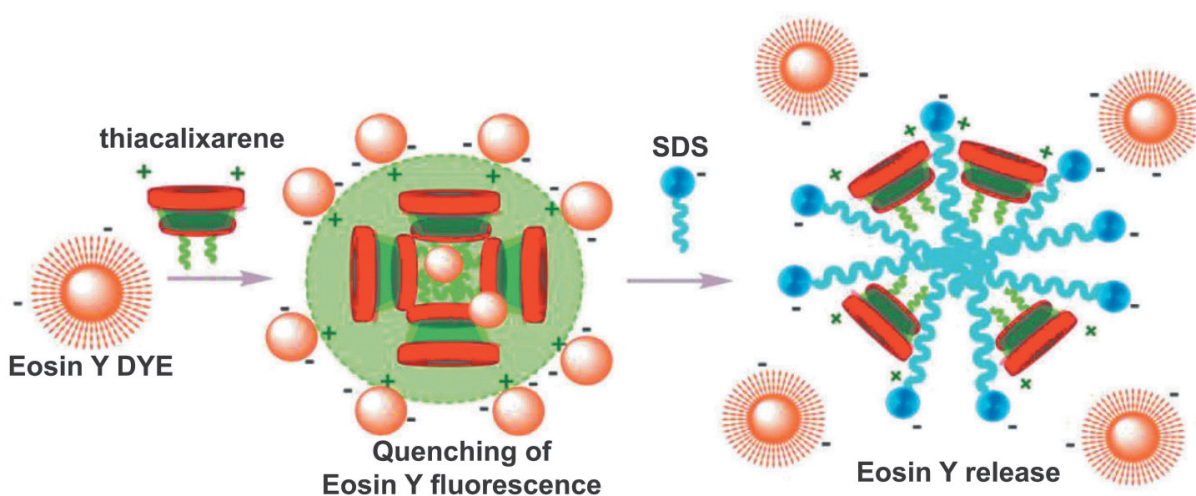

Figure 10. Fluorescent sensors based on the EY dye release.

measured by electrophoretic light scattering method are $+60-+70 \mathrm{mV}$ due to polycationic nature of macrocycles $\mathbf{1 1 5}$ and correspond to the formation of colloidal systems with high stability.

The binding of new polycationic macrocycles with nucleic acid was investigated using calf thymus DNA as model biopolymer and well-known DNA intercalator ethidium bromide. According to the dynamical, electroforetic light scattering data and fluorescent spectroscopy new polycationic macrocycles effectively interact with calf thymus DNA. Addition of all synthesized macrocycles 115, 116 below the critical aggregation concentration (CAC) does not lead to a significant change in the size of the calf thymus DNA, while at the concentrations higher than CAC a significant compression of DNA in 2-5 times is observed. ${ }^{[1,92]}$ Increased lipophilicity of the macrocycles leads to the formation of more compact lipoplex.

Calixarene lipophilicity effect was also shown for the interaction of water-soluble bis-ammonium thiacalix[4]arene derivatives $\mathbf{1 1 6}$ with bovine serum albumin (BSA) by fluorescence spectroscopy method. ${ }^{[88]}$ It was established that the fluorescence quenching of BSA by calixarenes is a result of the complex formation and intrinsic fluorescence of BSA is reduced through a static quenching. Measured binding constants $\left(\lg K_{\mathrm{a}}\right)$ are increased with calixarene lipophilicity growth: from $4.67\left(\mathrm{C}_{4}\right)$ up to $8.45\left(\mathrm{C}_{14}\right)$. So, electrostatic interactions of positive charged calixarenes with hydrophilic surface of BSA as well as the interactions of alkyl substituents with hydrophobic binding pocket of BSA (sub-domain IIA, comprising Trp-212 residue) govern the molecular recognition pattern.

Critical aggregation concentration of amphiphilic thiacalixarenes $\mathbf{1 1 6}$ determined by pyrene micellization method are 91, 59 and $33 \mu \mathrm{M}$, respectively. ${ }^{[92]}$ According to DLS data the diameter of these aggregates is around 130 $\mathrm{nm}$. Their electrokinetic potential corresponds to the positive charge of the headgroups of thiacalixarene derivatives and is about $+40 \mathrm{mV}$, which corresponds to the moderately stable colloids.

The presence of cationic headgroups in thiacalixarenes 116 makes them suitable for the strong interactions with anionic guests. ${ }^{[96]}$ Anionic dye Eosin Y (EY) forms the associates with positive charged thiacalixarenes 116, shifts $\mathrm{CAC}$ to the low concentration region $(2 \mu \mathrm{M})$ and decreases nanoaggregates size up to $90 \mathrm{~nm} \cdot{ }^{[92]}$ An addition of EY (10 mol \%) to thiacalixarene 116 solution leads to the decrease of aggregates surface charge from $\sim+45$ to $+20 \mathrm{mV}$. Thus, the anionic dye partly compensates the positive surface charge of the aggregates and their size decreases due to the less repulsion between head groups of thiacalixarene amphiphiles.

Associates of 116/EY were investigated as fluorescent probe based on the "off-on" switch of EY emission for the determination of sulfate-containing surface active substances (SAS) in the solution. ${ }^{[92]}$ It was found only sodium dodecyl sulfate (SDS) and sodium laureth sulfate (SLES) causes EY release from 116/EY, while other anionic, cationic and zwitterionic SAS form only mixed aggregates. An addition of such surfactants to these aggregates leads to the small multidirectional changes in fluorescence intensity without maximum shift. It clearly indicates that the dye remains inside of the aggregates, and the fluorescence intensity is defined by its translocation in the aggregate hydrophobic domains.

The appearance of free dye bands in the fluorescence and absorption spectra indicates on the competitive displacement of the dye molecules by investigated sulfate SAS in the aggregates (Figure 10). Moreover, sulfonate compounds of different nature (sodium polystyrene sulfonate and sodium $p$-toluenesulfonate) without hydrophobic alkyl substituents do not have significant influence on the fluorescence spectra. Thus, a key role in the fluorescent response of sulfonate containing compounds plays the combination of anionic sulfate group with hydrophobic alkyl fragment. The fluorescent response of thiacalixarene/EY associates is considerable from $3.5 \mu \mathrm{M}$ concentration of SDS. Obtained supramolecular associate is very promising for the future development of the fluorescent sensors based on the dye release.

\section{Conclusions}

We demonstrated the possibilities of synthesis of bifunctional tetrasubstituted thiacalix[4]arene derivatives in the 1,3-alternate conformation bearing two pairs of different substituents on opposite sides of the macrocycle scaffold. Unlike to distal disubstituted derivatives of conventional calix[4]arenes those of thiacalix[4]arenes are very unstable at the alkaline conditions. It was shown that they are hydrolyzed to the parent macrocycles in the presence of rather weak bases. The differences in the chemical behavior of the 
distal derivatives of calixarene and thiacalixarene can be explained by their structure features and possible mechanism of their hydrolysis was proposed. Mitsunobu reactions were successfully employed for the selective functionalization of the macrocycle lower rim.

An original approach was developed for the design of new type of amphiphilic compound based on bifunctional thiacalixarenes in the 1,3-alternate conformation containing two molecular domains with quite different properties located on opposite sides of the macrocycles central plane. One of them has lipophilic properties due to the introduction of long chain alkyl substituents. The other side of the macrocycle contains the polar binding sites, which are easily introduced by $\mathrm{CuAAC}$ click reactions.

The compounds synthesized were used to study the supramolecular properties of the thiacalix[4]arene derivatives, in particularly, self-assembly on the interfaces and their application for the chemosensors design with an tunable selectivity.

Acknowledgements. This work was supported by the Russian Science Foundation (Project No. 14-13-01151) and partly Ministry of Education and Science of Russian Federation (subsidy allocated to Kazan Federal University for the state assignment in the sphere of scientific activities).

\section{References}

1. Gutsche C.D. Calixarenes Revisited. Monographs in Supramolecular Chemistry. Cambridge: The Royal Society of Chemistry, 1998. $235 \mathrm{p}$.

2. Gutsche C.D. Calixarenes: an Introduction. 2nd ed. Cambridge: The Royal Society of Chemistry, 2008. 276 p.

3. Calixarenes in Action (Mandolini L., Ungaro R., Eds.). London: Imperial College Press, 2000. 271 p.

4. Calixarenes 2001 (Asfari Z., Bohmer V., Harrowfield J., Vicens J., Eds.). Netherlands: Kluver, 2001. 683 p.

5. Calixarenes in Nanoworld (Vicens J., Harrofield J., Eds.). Netherlands: Springer, 2007. 392 p.

6. Calixarenes and Beyond. (Neri P., Sessler J. L., Wang M.-X., Eds.) Netherlands: Springer, 2016. 1062 p.

7. Kumagai H., Hasegawa M., Miyanari S., Sugawa Y., Sato Y., Hori T., Ueda S., Kamiyama H., Miyano S. Tetrahedron Lett. 1997, 38, 3971-3972.

8. Iki N., Miyano S. J. Inclusion Phenom. Macrocycl. Chem. 2001, 41, 99-105.

9. Lhotak P. Eur. J. Org. Chem. 2004, 1675-1692.

10. Morohashi N., Narumi F., Iki N., Hattori T., Miyano S. Chem. Rev. 2006, 106, 5291-5316.

11. Agraval Y.K., Pancholi J.P. Indian J. Chem. 2007, 46A, 13721382.

12. Konovalov A.I., Antipin I.S. Mendeleev Commun. 2008, 18 , 229-237.

13. Kumar R., Lee Y.O., Bhalla V., Kumar M., Kim J.S. Chem. Soc. Rev. 2014, 43, 4824-4870.

14. Yamada M., Rajiv Gandhi M., Kunda U.M.R., Fumio H. J. Inclusion Phenom. Macrocycl. Chem. 2016, 85, 1-18.

15. Akdas H., Bringel L., Graf E., Hosseini M.W., Mislin G., Pansanel J., Cian A.D., Fisher J. Tetrahedron Lett. 1998, 39, 2311-2314.

16. Kovalenko V.I., Chernova A.V., Borisoglebskaya E.I., Katsyuba S.A., Zverev V.V., Shagidullin R.R., Antipin I.S., Solov'eva S.E., Stoikov I.I., Konovalov A.I. Russ. Chem. Bull. 2002, 51, 825-827.
17. Katsyuba S., Kovalenko V., Chernova A., Vandyukova E., Zverev V., Shagidullin R., Antipin I., Solovieva S., Stoikov I., Konovalov A. Org. Biomol. Chem. 2005, 3, 2558-2565.

18. Stoikov I.I., Omran O.A., Solovieva S.E., Latypov Sh.K., Enikeev K.M., Gubaidullin A.T., Antipin I.S., Konovalov A.I. Tetrahedron 2003, 59, 1469-1476.

19. Solovieva S.E., Grüner M., Omran A.O., Gubaidullin A.T., Litvinov I.A., Habicher W.D., Antipin I.S., Konovalov A.I. Russ. Chem. Bull. 2005, 54, 2104-2112.

20. Solovieva S.E., Kleshnina S.R., Kozlova M.N., Galiullina L.F., Gubaidullin A.T., Latypov Sh.K., Antipin I.S., Konovalov A.I. Russ. Chem. Bull. 2008, 57, 1477-1485.

21. Tyuftin A.A., Solovieva S.E., Murav'ev A.A., Polyantsev F.M., Latypov Sh.K., Antipin I.S. Russ. Chem. Bull. 2009, 58, $145-151$

22. Omran O.A., Antipin I.S. J. Inclusion Phenom. Macrocycl. Chem. 2014, 78, 121-126.

23. Stoikov I.I., Galukhin A.V., Zaikov E.N., Antipin I.S. Mendeleev Commun. 2009, 19, 193-195.

24. Galukhin A.V., Zaikov E.N., Antipin I.S., Konovalov A.I., Stoikov I.I. Macroheterocycles 2012, 5, 266-274.

25. Kozlova M.N., Ferlay S., Solovieva S.E., Antipin I.S., Konovalov A.I., Kyritsakas N., Hosseini M.W. Dalton Trans. 2007, 5126-5131.

26. Kozlova M.N. Molecular Tectonics: Nontubular Coordination Networks on the Thiacalix[4]arene Backbone, PhD thesis. Strasbourg: Univercity Strasbourg, 2008. p. 1-186.

27. Epifanova N.A., Popova E.V., Solovieva S.E., Latypov Sh.K., Antipin I.S., Konovalov A.I. Macroheterocycles 2013, 6, 47-52.

28. Murav'ev A.A., Galieva F.B., Strel'nik A.G., Nugmanov R.I., Grüner M., Solov'eva S.E., Latypov Sh.K., Antipin I.S., Konovalov A.I. Russ. J. Org. Chem. 2015, 51, 1334-1342.

29. Ovsyannikov A., Lang M.N., Ferlay S., Solovieva S.E., Antipin I.S., Konovalov A.I., Kyritsakas N., Hosseini M.W. Dalton Trans. 2013, 42, 116-126.

30. Ovsyannikov A., Ferlay S., Solovieva S.E., Antipin I.S., Konovalov A.I., Kyritsakas N., Hosseini M.W. Dalton Trans. 2013, 42, 9946-9953.

31. Ovsyannikov A.S., Noamane M.H., Abidi R., Ferlay S., Solovieva S.E., Antipin I.S., Konovalov A.I., Kyritsakas N., Hosseini M.W. Cryst. Eng. Commun. 2016, 18, 691-703.

32. Kozlova M.N., Ferlay S., Kyritsakas N., Hosseini M.W., Solovieva S.E., Antipin I.S., Konovalov A.I. Chem. Commun. 2009, 2514-2516.

33. Iki N., Narumi F., Fujimoto T., Morohashi N., Miyano S. J. Chem. Soc., Perkin Trans. 2 1998, 2745-2750.

34. Akdas H., Mislin G., Graf E., Hosseini M.W., Cian A.D., Fisher J. Tetrahedron Lett. 1999, 40, 2113-2116.

35. Lhotak P., Stastny V., Zlatuskova P., Stibor I., Michlova V., Tkadlecova M., Havlicek J., Sykora J. Collect. Czech. Chem. Commun. 2000, 65, 757-771.

36. Akdas H., Jaunky W., Graf E., Hosseini M.W., Planeix J.M., Cian A.D., Fisher J. Tetrahedron Lett. 2000, 41, 3601-3606.

37. Iki N., Narumi F., Suzuki T., Sugawara A., Miyano S. Chem. Lett. 1998, 1065-1066.

38. Muravev A.A., Burilov V.A., Solovieva S.E., Strelrnik A.G., Latypov Sh.K., Bazanova O.B., Sharafutdinova D.R., Antipin I.S., Konovalov A.I. Russ. Chem. Bull. 2014, 63, 214-222.

39. Galukhin A.V., Shabalin K.V., Antipin I.S., Konovalov A.I., Stoikov I.I. Mendeleev Commun. 2013, 23, 41-43.

40. Galukhin A.V., Stoikov I.I. Mendeleev Commun. 2014, 24, 82-84.

41. Mostovaya O.A., Agafonova M.N., Galukhin A.V., Khayrutdinov B.I., Islamov D., Kataeva O.N., Antipin I.S., Konovalov A.I., Stoikov I.I. J. Phys. Org. Chem. 2014, 27, 57-65.

42. Stoikov I.I., Yushkova E.A., Zhukov A.Yu., Zharov I., Antipin I.S., Konovalov A.I. Tetrahedron 2008, 64, 7489-7497.

43. Stoikov I.I., Yushkova E.A., Zhukov A.Yu., Zharov I., Antipin I.S., Konovalov A.I. Tetrahedron 2008, 64, 7112-7121. 
44. Stoikov I.I., Yushkova E.A., Bukharaev A.A., Biziaev D.A., Selivanovskaya S.Yu., Chursina M.A., Antipin I.S., Konovalov A.I., Zharov I. J. Phys. Org. Chem. 2012, 25, 1177-1185.

45. Yushkova E.A., Zaikov E.N., Stoikov I.I., Antipin I.S. Russ. Chem. Bull. 2009, 58, 101-107.

46. Zhukov A.Yu., Fink T.A., Stoikov I.I., Antipin I.S. Russ. Chem. Bull. 2009, 58, 1007-1014.

47. Stoikov I.I., Zhukov A.Yu., Agafonova M.N., Sitdikov R.R., Antipin I.S., Konovalov A. Tetrahedron 2010, 66, 359-367.

48. Andreyko E.A., Padnya P.L., Stoikov I.I. J. Phys. Org. Chem. 2015, 28, 527-535.

49. Kleshnina S.R., Long N.F., Solov'eva S.E., Antipin I.S., Konovalov A.I. Russ. J. Org. Chem. 2015, 51, 430-435.

50. Stoikov I.I., Nasibullin R.Z., Smolentsev V.A., Gafiullina L.I., Zhukov A.Yu., Puplampu J.B., Antipin I.S., Konovalov A.I. Mendeleev Commun. 2006, 16, 248-249.

51. Podyachev S.N., Sudakova S.N., Syakaev V.V., Shagidullin R.R., Galiev A.K., Konovalov A.I. Mendeleev Commun. 2006, 16, 297-299.

52. Stoikov I.I., Yushkova E.A., Zharov I., Antipin I.S., Konovalov A.I. Tetrahedron 2009, 65, 7109-7114.

53. Podyachev S.N., Burmakina N.E., Sudakova S.N., Syakaev V.V., Konovalov A.I. Supramol. Chem. 2010, 22, 339-346.

54. Yushkova E.A., Stoikov I.I., Zhukov A.Yu., Puplampu J.B., Rizvanov I.Kh., Antipin I.S., Konovalov A.I. RSC Advances 2012, 2, 3906-3919.

55. Pod'yachev S.N., Sudakova S.N., Syakaev V.V., Burmakina N.E., Konovalov A.I. Russ. J. Org. Chem. 2010, 46, 1162-1166.

56. Podyachev S.N., Barsukova T.A., Bukharov S.V., Syakaev V.V., Sudakova S.N., Nugumanova G.N., Konovalov A.I. Russ. J. Org. Chem. 2012, 48, 1360-1365.

57. Rao P., Hosseini M.W., Cian A.D., Fischer J. Chem. Commun. 1999, 2169-2170.

58. Katsyuba S.A., Zvereva E.E., Chernova A.V., Shagidullin A.R., Solovieva S.E., Antipin I.S., Konovalov A.I. J. Inclusion Phenom. Macrocycl. Chem. 2008, 60, 281-291.

59. Ovsyannikov A.S., Ferlay S., Solovieva S.E., Antipin I.S., Konovalov A.I., Kyritsakas N., Hosseini M.W. Russ. Chem. Bull. 2015, 64, 1955-1962.

60. Ovsyannikov A., Ferlay S., Solovieva S.E., Antipin I.S., Konovalov A.I., Kyritsakas N., Hosseini M.W. Inorg. Chem. 2013, 52, 6776-6778.

61. Matsumiya H., Terazono Y., Iki N., Miyano S. J. Chem. Soc., Perkin Trans. 2 2002, 1166-1172.

62. Lhotak P., Kaplanek L., Stibor I., Lang J., Dvorakova H., Harbal R., Sykora J. Tetrahedron Lett. 2000, 41, 9339-9344.

63. Iki N., Morohashi N.N., Narumi F., Fujimoto T., Suzuki T., Miyano S. Tetrahedron Lett. 1999, 40, 7337-7341.

64. Morohashi N., Katagiri H., Iki N., Yamane Y., Kabuto C., Hattori T., Miyano S. J. Org. Chem. 2003, 68, 2324-2333.

65. Bhalla V., Kumar M., Hattori T., Miyano S. Tetrahedron 2004, $60,5881-5887$

66. Stoikov I.I., Ibragimova D.S., Shestakova N.V., Krivolapov D.B., Litvinov I.A., Antipin I.S., Konovalov A.I., Zharov I. Supramol. Chem. 2009, 21, 564-571.

67. Bitter I., Csokai V. Tetrahedron Lett. 2003, 44, 2261-2265.

68. Burilov V.A., Ibragimova R.R., Nugmanov R.I., Sitdikov R.R., Islamov D.R., Kataeva O.N., Solovieva S.E., Antipin I.S. Russ. Chem. Bull. 2015, 64, 2114-2124.

69. Muravev A.A., Solovieva S.E., Latypov Sh.K., Antipin I.S., Konovalov A.I. Phosphorus, Sulfur Silicon Relat. Elem. 2013, $188,499-502$.

70. Burilov V., Valiyakhmetova A., Mironova D., Safiullin R., Kadirov M., Ivshin K., Kataeva O., Solovieva S., Antipin I. RSC Adv. 2016, 6, 44873-44877.
71. Solovieva S.E., Popova E.V., Omran A.O., Gubaidullin A.T., Kharlamov S.V., Latypov Sh.K., Antipin I.S., Konovalov A.I. Russ. Chem. Bull. 2011, 60, 486-498.

72. Grootenhuis P.D.J., Kollman P.A., Groenen L.C., Reinhoudt D.N., van Hummel G.J., Ugozzoli F., Andreetti G.D. J. Am. Chem. Soc. 1990, 112, 4165-4176.

73. Zeng X., Leng X., Chen L., Sun H., Xu F., Li Q., He X., Zhang Z.-Z. J. Chem. Soc., Perkin Trans. 2 2002, 796-801.

74. Collins E.M., McKervey M.A., Madigan E., Moran M.B., Owens M., Ferguson G., Harris S.J. J. Chem. Soc., Perkin Trans. 1 1991, 3137-3142.

75. Dvorakova H., Lang J., Vlach J., Sykora J., Cyajan M., Himl M., Pojarova M., Stibor I., Lhotak P. J. Org. Chem. 2007, 72, 7157-7166.

76. Kasyan O. Thondorf I., Bolte M., Kalchenko V., Boehmer V. Acta Cryst. C 2006, C62, o289-o294.

77. Dudic M., Lhotak P., Petrickova H., Stibor I., Lang K., Sykora J. Tetrahedron 2003, 59, 2409-2415.

78. Bhalla V., Kumar M., Kabuto C., Hattori T., Miyano S. Chem. Lett. 2004, 33, 184-185.

79. Van Leeuwen F.W.B., Beijleveld H., Kooijman H., Spek A.L., Verboom W., Reinhoudt D.N. J. Org. Chem. 2004, 69, 39283936.

80. Dudic M., Lhotak P., Stibor I., Petrickova H., Lang K. New J. Chem. 2004, 28, 85-90.

81. Bhalla V., Kumar M., Katagiri H., Hattori T., Miyano S. Tetrahedron Lett. 2005, 46, 121-124.

82. Latypov Sh.K., Kharlamov S.V., Muravev A.A., Balandina A.A., Solovieva S.E., Antipin I.S., Konovalov A.I. J. Phys. Org. Chem. 2013, 26, 407-414.

83. Solovieva S.E., Murav'ev A.A., Latypov Sh.K., Antipin I.S., Konovalov A.I. Dokl. Chem. 2011, 438, 170-174.

84. Solovieva S.E., Muravev A.A., Zakirzyanov R.T., Latypov Sh.K., Antipin I.S., Konovalov A.I. Macroheterocycles 2012, $5,17-22$.

85. Muravev A.A., Solovieva S.E., Kochetkov E.N., Mel'nikova N.B., Safiullin R.A., Kadirov M.K., Latypov Sh.K., Antipin I.S., Konovalov A.I. Macroheterocycles 2013, 6, 302-307.

86. Muravev A., Galieva F., Bazanova O., Sharafutdinova D., Solovieva S., Antipin I., Konovalov A. Supramol. Chem. 2016, 28, 589-600.

87. Burilov V.A., Nugmanov R.I., Ibragimova R.R., Solovieva S.E., Antipin I.S. Mendeleev Commun. 2015, 25, 177-179.

88. Burilov V.A., Mironova D.A., Ibragimova R.R., Solovieva S.E., Antipin I.S. BioNanoSci. 2016, 6, 427-430.

89. Jie K., Zhou Y., Yao Y., Huang F. Chem. Soc. Rev. 2015, 44, 3568-3587.

90. Tauran Y., Coleman A.W., Perret F., Kim B. Curr. Org. Chem. 2015, 19, 2250-2270.

91. Ibragimova R.R., Burilov V.A., Aimetdinov A.R., Mironova D.A., Evtugyn V.G., Osin Y.N., Solovieva S.E., Antipin I.S., Macroheterocycles 2016, 9, 433-441.

92. Burilov V.A., Mironova D.A., Ibragimova R.R., Nugmanov R.I., Solovieva S.E., Antipin I.S. Colloids Surf., A 2017, 515, 41-49.

93. Mel'nikova N.B., Kochetkov E.N., Solov'eva S.E., Popova E.V., Antipin I.S., Bol'shakova A.E., Zhil'tsova O.E., Konovalov A.I. Russ. Chem. Bull. 2011, 60, 1948-1955.

94. Solovieva S.E., Safiullin R.A., Kochetkov E.N., Melnikova N.B., Kadirov M.K., Popova E.V., Antipin I.S., Konovalov A.I. Langmuir 2014, 30, 15153-15161.

95. Burilov V.A., Mironova D.A., Ibragimova R.R., Solovieva S.E., Antipin I.S., König B. RSC Adv. 2015, 5, 101177-101185.

96. Burilov V.A., Fatikhova G.A., Mironova D.A., Solovieva S.E., Antipin I.S. Macroheterocycles 2015, 8, 409-414. 